\title{
LIETUVOS DIDŽIOSIOS KUNIGAIKŠTYSTĖS KARIUOMENĖ BARO KONFEDERACIJOS METAIS (1768-1772 M.)
}

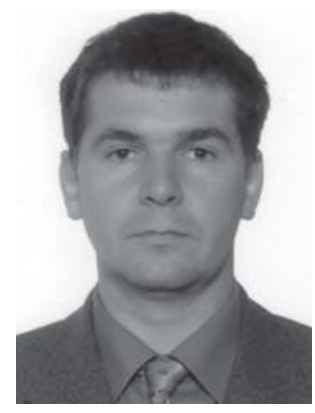

\section{Ivadas}

\author{
Dr. Valdas RAKUTIS, \\ Gen. J. Žemaičio Lietuvos karo akademija, \\ Vytauto Didžiojo universitetas
}

Lietuvos kariuomenė XVIII a. išgyveno nuopuolio laikotarpi, tačiau politiniuose ivvykiuose ji pati, kai kurie daliniai ar vadai suvaidino nemenką vaidmenį. Ginkluota jèga, kokia menka ji bebūtų, krizių sąlygomis visada turi didesnę reikšmę nei taikos metais, todèl jos pasyvumas ar aktyvumas politinių įvykių sūkuryje, kuomet buvo baigtas Čartoriskių reformų laikotarpis ir įvykęs pirmasis padalijimas, yra atskiro straipsnio verta tema.

Baro konfederacijos susikūrimas, veikla ir veiksmai Lietuvos Didžiojoje kunigaikštystejje yra Lietuvos istoriografijoje gana mažai ištyrinèta tema lyginant su 1788-1794 m. laikotarpiu. Apie Baro konfederaciją yra rašiusi Vanda Daugirdaitė-Sruogienè ir jos pateikta informacija ilgą laiką tebuvo vienintele lietuviška medžiaga. Svarbiausia paskutiniųu metų studija yra Vydo Dolinsko monografija, skirta Simono Kosakovskio politinei ir karinei veiklai Lietuvos Didžiojoje kunigaikštystejje 1763-1794 m. Čia Baro konfederacijos veiklos laikotarpiui skirtas visas trečiasis skyrius. Šiame darbe visapusiškai ir išsamiai ištirti ne tik politiniai įvykiai, tiesiogiai susiję su Simono Kosakovskio karine veikla, bet ir pateiktas pakankamai platus įvykių Lietuvoje kontekstas, leidžiantis kompensuoti žymias Lietuvos istoriografijos spragas apibūdinant LDK vidaus situaciją bei jungiant svarbius Lietuvos 
kariuomenès istorijai tirti įvykius. Ypač naudingi pasirodè tyrimai, susiję su $1771 \mathrm{~m}$. kampanija, kur tirti tiek paties Simono Kosakovskio divizijos, tiek kitų Lietuvoje veikusių dalinių veiksmai, Mykolo Kazimiero Oginskio žygio motyvai ir aplinkybès.

Detalios informacijos apie kai kuriuos vadus ir jų dalinius (ypač apie Bielako ir Koryckio pulkus) buvo galima rasti Lenkijos biografiniame žodyne.

Straipsnio tikslas - apžvelgti Lietuvos kariuomenès veiklą 1768-1772 m. Baro konfederacijos metu. Straipsnyje keliami šie uždaviniai:

- İvertinti vyriausiosios vadovybès ir dalinių vadų politinę laikyseną;

- Atlikti kiekybinę ir kokybinę kariuomenès analizę;

- Apžvelgti Lietuvos kariuomenès ir atskirų jos dalinių karinę veiklą, atskirai tiriant mūšius ir susidūrimus;

- İvertinti, kokị poveiki kariuomenei padarė Baro konfederacijos kovos.

Pagrindiniu straipsnio šaltiniu buvo Lietuvos valstybės istorijos archyve (LVIA) saugomi Lietuvos karo komisijos archyvo dokumentai: komisijos darbo protokolai, îsakymai ir dalinių raportai, ypač vertinga pasirodè dalinių būklès ir patirtų nuostolių raportai. Papildomos informacijos apie karo veiksmus pavyko rasti Nacionalinèje Martyno Mažvydo bibliotekoje esančiame rankraščių skyriuje.

\section{Bendra politinė situacija ir Lietuvos kariuomenė $1768 \mathrm{~m}$.}

Žinoma, kad Baro konfederacija ir platesnis visuomeninis judejjimas buvo glaudžiai susijęs su $1764 \mathrm{~m}$. tarpuvaldžio ir Radomo-Slucko konfederacija 1767 m. Pagrindinis konfederacijos šūkis „už tikejjimą ir laisvę“ išreiškẻ nepasitenkinimą Stanislovo Augusto Poniatovskio elekcija, kurioje lemianti jèga buvo Rusijos pozicija ir kariuomene bei Rusijos spaudimas sulyginti visu religijų ar, kaip dabar sakytume, konfesijų politines ir kitokias teises, taigi pagrindiniai konfederatų priešai buvo Stanislovas Augustas Poniatovskis, Čartoriskių Familija ir Rusija, ypač jos ambasada ir kariuomenè. Tai buvo iš esmès konservatyvus judejjimas, nukreiptas i „senovès“ išsaugojimą, garbės gynimą, neturèjęs stiprios politinės programos nei gerai apskaičiuotos strategijos, tačiau randantis atsaką to meto bajorijos nuostatose ir mąstymo stereotipuose, todèl gerai suprantamas ir aktyviai remiamas. Rusijos įžūli politika pajudino du svarbiausius Lenkijos ir Lietuvos piliečiu stabus - tikejjimą ir laisvę - taip, kaip juos tuo metu suprato žmonès, todèl bajorijos laikysena buvo lengvai prognozuojama ir neišvengiamai sąlygojo 
vienokios ar kitokios formos pasipriešinimą, kuris tradiciškai peraugo ị ginkluotą kovą. Ypač aktyvumu pasižymėjo pamaldi, mažai išprususi ir greitai i avantiūras îsivelianti vidutinè ir smulkioji bajorija, sudariusi nemažą dali Lietuvos kariuomenés karininkų ir draugų.

Būdama nukreipta prieš valdovą ir jo šalininkus, Baro konfederacija turejo priešų krašto viduje. Po 1764 m. pertvarkymų aktyvieji Familijos šalininkai buvo nustumti nuo svarbiausių valstybinių postų ar jų įtaka apribota, susidariusį vakuumą užèmė „savi žmonès“, dažnai susiję ne tik su Familija, bet ir su Rusija, kurie natūraliai negalèjo būti aktyvūs konfederatų šalininkai. Nedaugelis iš jų tiesiogiai kariavo kartu su Rusijos kariuomene, kaip LDK artilerijos generolas Pranciškus Ksaveras Branickis, - dauguma stengèsi būti ivvykių nuošalyje slapta palaikydami santykius su abiem pusėmis ar aktyviai, vieniems giminės nariams remiant vieną pusę, kitiems kitą. Tokios atsargios politikos laikèsi dauguma Lietuvos giminių, susijusių su Familija.

Lietuvos kariuomenès bendrają laikyseną lėmė didžiojo etmono Mykolo Kazimiero Oginskio, realiai vadovavusio kariuomenei nuo 1764 m., pozicija. Turėdamas savo rankose Lietuvos karo komisiją ir galimybę teikti karinius laipsnius, etmonas Oginskis savo rankose turejjo pagrindinius svertus, kurie jam išsprūsdavo tik kariniams konfederatų daliniams įsiveržus ị kraštą ir tiesiogiai paveikus dalinių vadus. Tik po $1771 \mathrm{~m}$. pralaimèjimo Oginskio itaka sumažejo, tačiau liko pagrindiniu faktoriumi, formuojančiu politines visos kariuomenès nuostatas.

Lietuvos kariuomenè turèjo vyriausiają ir dalinių vadovybę. Vyriausiuoju kariuomenę valdančiu organu nuo 1764 m. buvo Lietuvos karo komisija, kuri susirinkdavo posėdžiams kartą per pusmetį. Komisiją sudarė Seimo paskirti senato ir riterių luomo deputatai, prie kurių, reikalui esant, prisidedavo kariuomenès atstovai. Vadovavo komisijai etmonai arba vyriausi pagal pareigas deputatai. Etmonai formaliai buvo praradę savo valdžią kariuomenei, tačiau išsaugojo pagrindinius svertus, o Mykolas Kazimieras Oginskis realiai dominavo visame komisijos darbe, būdamas tikruoju jos pirmininku nuo pat 1765 m., kai jam buvo pavesta tiesiogiai vadovauti Vilniaus igulai ir didžiajai ir stipriausiai kariuomenès daliai, o $1768 \mathrm{~m}$. jam buvo be eilès suteikta LDK didžiojo etmono buožè. Komisijos narys Jozefas Sosnovskis buvo menkesnè figūra, tačiau jo tyli laikysena nebuvo jau tokia nereikšminga.

Generalinis Lietuvos kariuomenès štabas iš esmès egzistavo popieriuje, nesirinkdamas ir nevykdydamas to meto štabams ịprastos veiklos. Ittakos galejjo turèti tik atskiri asmenys, susiję su Oginskiu kitais saitais. 
Didelę reikšmę kariuomenès reikalams turèjo Iždo komisija, mokẻjusi kariuomenei algas. Suirutès, kuri neišvengiamai prasidejjo dẻl konfederatų ir Rusijos kariuomenės veiksmų ir vykdomų rekvizicijų, sąlygomis, LDK Iždo komisija galejo teikti prioritetus, sudaryti kliūtis ar jas šalinti ir taip veikti LDK kariuomenès gyvenimą.

Kariuomenès dalinių laikyseną, ypač konfederatams pasiekus jų dislokacijos vietas, dažnai lèmé dalinių vadai. Priešakinès sargybos pulkai buvo ypač svarbūs tiek dẻl jų tinkamumo konfederaciniam karui, tiek dẻl jų kovinès parengties, todèl visos suinteresuotos pusès stengèsi išlaikyti savo įtaką. Ypač svarbūs buvo Bielako ir Koryckio totorių pulkai, Seimo sprendimu grịže i Lietuvą iš Septynerių metų karo tuoj po Augusto III mirties. Šie daliniai ne tik turejo kovinès patirties, bet ir pasižymejjo drausme - reta savybe Lietuvos kariuomeneje. Jau nuo $1765 \mathrm{~m}$. jiems vadovauti buvo paskirtas LDK lauko raštininkas Sosnovskis - Karo komisijos narys ir politiškai svarbi figūra. Šis vadovavimas truko iki pat Baro konfederacijos kovų, tik 1771 m. liepos $17 \mathrm{~d}$. jis atsisake šiu pareigų motyvuodamas tuo, kad negyvena Lietuvoje ${ }^{1}$. Antra pagal svarbą Lietuvos kariuomenès dalis buvo trys raitieji, arba dragūnų, du pėstininkų regimentai ir dvi atskirosios pėstininkų vẻliavos, sudarę Svetimšalių autoramento pagrindą. Artilerijos korpusas buvo per daug nepaslankus, nedidelis ir mažai ką galëjo padaryti būdamas Vilniuje - Rusijos kariuomenès kontroliuojamame mieste. Tiek dragūnų, tiek pėstininkų, tiek artilerijos jègas, galinčias veikti tik didesniais junginiais, labiausiai varžè jų išbarstymas po visą Didžiają Kunigaikštystę. Kiekvienas bandymas koncentruoti dalinius ị vieną vietą kẻlė Rusijos ir jos kariuomenès nepasitikejjimą ir galëjo paskatinti išformuoti LDK kariuomenę, taip paliekant karininkus ir kareivius be pragyvenimo šaltinio ir padarytos karjeros. Tautinés kavalerijos vẻliavos buvo sugrupuotos ị tris Tautinès kavalerijos divizijas, vadovaujamas regimentorių. Tai, kas trukdè reguliariems daliniams, buvo privalumas iš esmès nereguliariems smulkiems tautinès kavalerijos padaliniams prisidéti prie konfederatų. Prastai aprengti, nežinantys karinès drausmès, beveik be jokio kovinio parengimo, husarai ir petihorai buvo sudaryti iš politiškai aktyvių vidutinių ir smulkiųjų bajorų - idealių kovotojų konfederatams jų partizaniniame kare.

Kariuomenès dydis kito, bet buvo artimas etatuose ir reguliaminuose numatytam dydžiui. Tuo metu tebegaliojo $1717 \mathrm{~m}$. etatas, kuriame buvo numatytos algų porcijos ir dalinių nuolatinès dislokacijos vietos su gaunamų

\footnotetext{
${ }^{1} 17650809$ atsakymas ị valdovo raštą. LVIA, f. SA, b. 18249, 1. 27-28. İrašas Karo komisijos sprendimų knygoje. LVIA, f. SA, b. 18252, 1. 15.
} 
algų šaltiniais, vadinamosios konsistencijos. Tautinio autoramento daliniuose - husarų, petihorų ir lengvosiose vèliavose - karininkai imdavo kelių kareivių algą: pulkininkas gaudavo 12, leitenantas 6 porcijų algą, o iš kiekvienos porcijos buvo išlaikomi du kariai - draugas ir eilinis. Taigi trijose 100, 70 ir 46 porcijų husarų vẻliavose tarnavo 3 pulkininkai (po 12 porcijų), du jaunesnieji karininkai - leitenantas ir vèliavininkas (6 ir 3 porcijos), devyni muzikantai ir 60 porų, iš viso 135 kariai ir 120 žirgų. Taigi visa Tautinès kavalerijos divizija iš esmès sudarè vieną kavalerijos pulką. Svetimšalių autoramento dalinių porcijų skaičius neatitiko tikrojo karių skaičiaus, nes etatuose nebuvo numatytos svarbios išlaidos. Reguliaminai papilde etatą, nurodydami tikslų karininkų ir karių skaičių, algas, galimų išlaidų dydị ir paskirtị ir daug kitos informacijos.

1 lentelė. Lietuvos kariuomenès dydis kovų išvakarèse ${ }^{2}$

\begin{tabular}{|l|c|c|c|c|}
\hline \multicolumn{1}{|c|}{ Dalinio pavadinimas } & $\begin{array}{c}\mathbf{1 7 1 7} \mathbf{~ m .} \\
\text { etate } \\
\text { numa- } \\
\text { tyta }\end{array}$ & $\begin{array}{c}\text { Regulia- } \\
\text { minuose } \\
\text { numatyta }\end{array}$ & $\begin{array}{c}\text { Turèjo } \\
\text { būti pagal } \\
\text { turimus } \\
\text { dalinių } \\
\text { raportus }\end{array}$ & $\begin{array}{c}\text { Galëjo } \\
\text { būti } \\
\text { żmonių }\end{array}$ \\
\hline Generalinis štabas & 15 & & 15 & \\
\hline Tautinis autoramentas & 400 & & & \\
\hline Husarų vėliavos & 1200 & & & \\
\hline Petihorų vėliavos & 700 & $\begin{array}{c}1764 \mathrm{~m} . \\
\text { prijungti } \\
\text { du totorių } \\
\text { pulkai }\end{array}$ & & \\
\hline $\begin{array}{l}\text { Priešakinès sargybos (len- } \\
\text { gvosios, totorių ir kazokų) } \\
\text { veliavos }\end{array}$ & & & & \\
\hline Svetimšalių autoramentas & & & & \\
\hline Dragūnai (raitieji regimentai) & & & & \\
\hline
\end{tabular}

21717 m. etato duomenys pateikti pagal Volumina legum; reguliaminų duomenys pateikti pagal: Rakutis V. Lietuvos kariuomenès organizaciją reglamentuojantys dokumentai 1717-1775 m.// Karo archyvas, t. XVIII, Vilnius, 2003. Trečioji ir ketvirtoji grafos sudarytos pagal turimus dalinių raportus, juose nurodytose grafose turi būti (ma być, być powinno) ir iš viso (summa osób): JKM pèstininmkų gvardijos leibregimentas; DB raitelių regimentas; LB raitelių regimentas 1767 0630 Vysokije. VU RS F4 - 11483; Pinsko regimentas DB pèstininkų regimentas 17670601 Vilniuje. VU RS F4 -11481; LB pėstininkų regimentas 17670401 Slonime. VU RS F. 4 -11480. 


\begin{tabular}{|l|c|c|c|c|}
\hline $\begin{array}{l}\text { JKM raitelių gvardijos leibre- } \\
\text { gimentas }\end{array}$ & 600 & 306 & & \\
\hline DB raitelių regimentas & 300 & $\begin{array}{c}(1737 \mathrm{~m} ., \\
1768 \mathrm{~m} .) \\
202\end{array}$ & & \\
\hline LB raitelių regimentas & 300 & $\begin{array}{c}(1737 \mathrm{~m} ., \\
1768 \mathrm{~m} .) \\
202\end{array}$ & 198 & $203-205$ \\
\hline Pinsko regimentas & 300 & & & \\
\hline Pėstininkai: & 1000 & 620 & 626 & 290 \\
\hline $\begin{array}{l}\text { JKM péstininkų gvardijos } \\
\text { regimentas }\end{array}$ & 425 & $\begin{array}{c}(1737 \mathrm{~m} .) \\
289\end{array}$ & 290 & 290 \\
\hline DB pėstininkų regimentas & 425 & $\begin{array}{c}(1737 \mathrm{~m} .) \\
289\end{array}$ & 290 & \\
\hline LB pėstininkų regimentas & 150 & 122 & & \\
\hline DB janičarų (vengrų) vėliava & 100 & & & \\
\hline LB janičarų (vengrų) vėliava & 60 & & & \\
\hline $\begin{array}{l}\text { LDK kanclerio janičarų (ka- } \\
\text { zokų) vėliava }\end{array}$ & 100 & & & \\
\hline $\begin{array}{l}\text { Vyriausiojo tribunolo janiča- } \\
\text { rų vėliava }\end{array}$ & 150 & $118-120$ & & \\
\hline Artilerijos korpusas & & & \\
\hline
\end{tabular}

Tautinio autoramento husarų ir petihorų vèliavos buvo skirstomos į nenuolatinès sudėties divizijas, kurioms vadovavo vienos iš jų leitenantas, vadintas regimentoriumi. Pavyzdžiui, Žemaitijos divizijoje 1770 m. gruodžio pab. buvo 3 husarų ir 7 petihorų véliavos, kuriose buvo 504 žirgų porcijos. Realus skaičius gerokai skyrėsi. Kaip rodo labai informatyvi Trakų kašteliono Liudviko Platerio petihorų vẻliavos medžiaga, realiai tarnybai tiko tik eiliniai, trimitininkai ir du draugai, kurių vienas èjo vėliavos vado - vietininko pareigas, o draugas - deputatas rinko vẻliavai priklausančius mokesčius. Už savo darbą visi tikri kariai gaudavo papildomas priemokas, kurias mokėdavo likusieji nuo gaunamų žirgų porcijų kiekio. Nuo kiekvienos porcijos 20 auksinų buvo mokama deputatui, taip pat buvo mokamos algos eiliniams (40 auksinų) bei kitos priemokos amunicijai, žirgams ir kitoms reikmėms. Visa tai sudare 168 auksinus nuo žirgo porcijos. Karininkai papildomai išlaikẻ draugą - vietininką (iš viso 500 auksinų), mokejjo po 20 auksinų nuo žirgo porcijos 
deputatui ir 100 auksinų trimitininkui. Taip pat kartą per metus eilinių karių žirgai turejjo dalyvauti mokymuose, kad nebijotų šūvių. Taigi realiai tarnaujantys kariai gaudavo reikalingus priedus, leidusius išsilaikyti ir užtikrinti pagrindines funkcijas taikos metu, tačiau ir likusieji nelikdavo nuskriausti: draugams likdavo 204 auksinai, vẻliavininkui 664, o leitenantui net 2388 auksinai. Tiesa, kartais reikèdavo skirti pinigų uniformoms pirkti, o vienam iš pulkininkų ar leitenantų divizijoje tekdavo eiti regimentoriaus pareigas. Tad 40 žirgu porcijų vẻliavą sudarydavo tik vietininkas, trimitininkas ir 9-10 eilinių, iš viso 11-12 žmonių ( $31,25 \%$ ), o visa kavalerijos divizija tesudarè vieną tipišką kavalerijos eskadroną, sudarytą iš 130-150 karių.

Kiekybinis tyrimas jau parodè, kad Lietuvos kariuomenė iki $1768 \mathrm{~m}$. buvo nedidelè, bet aprūpinta alga, ginklais, uniforma, iš dalies žirgais ir artilerija, taigi formaliai galëjo būti laikoma pakankama jẻga, galinčia kovoti lauko mūšyje, tačiau taip atrodo tik žiūrint ị popierių, kuriame išdèstyti skaičiai. Iš tikrujų visa Lietuvos kariuomenè negalèjo būti surinkta ị vieną vietą, toli nuo savo konsistencijos vietų, o ir prasmès nedaug tebuvo, nes dalis kariuomenès nebuvo skirta karui. Lietuvos kariuomené vykdė daug karo meto kariuomenei nebūdingų funkcijų: malšino neramumus ir maištus, saugojo pasienị ir muitines, lydèjo vadus ir svarbius konvojus, be to, ne visi tiko tarnybai lauko sąlygomis. Dalis karių, ypač karininkų, buvo išleisti atostogų, taip mažinant mokesčių naštą. Komputinè kariuomenė neturejjo numatytų išlaidų. Kitas dalykas, kad kariuomenès nebuvo galima surinkti greitai, ypač priešui ịsiveržus ị krašto gilumą, tuo labiau vykdant okupaciją. Be to, pilietinio karo sąlygomis visada atsiras žmonių, palaikančių kitą pusę dẻl asmeninių, politinių ar konfesinių sumetimų, todẻl didelę reikšmę turèjo patikimumas, kuris dažnai nesutapdavo su profesiniais sugebejimais. Taigi geriausia buvo remtis tik tam tikrais daliniais ir rinktinemis komandomis iš visų dalinių, taip atrenkant tegu ir nedidelę, bet iš esmès kovingą diviziją.

Daug svarbesne už kiekybinę reikètų laikyti kokybinę Lietuvos kariuomenès charakteristiką - tą dydị, kuris retai kada ịvertinamas istorikų darbuose, nesistengiant suprasti, kas gi slypi už terminų „reguliari kariuomené“, komputo kareiviai, tautinè kavalerija, svetimšalių autoramentas. Pabandysime tokią charakteristiką pateikti.

Vadai. Etmonų pareigos Respublikoje jau seniai buvo dalijamos kaip vienas iš aukščiausių urẻdų, todẻl etmonai visą XVIII a. buvo politiškai aktyvūs, turintys gerą užnugarị didikai, kurių kariniai sugebejjimai buvo veikiau atsitiktinumas nei taisyklè. Iš tikrųjų nè vienas XVIII a. Lietuvos etmonas 
neturejjo tokio rango kariškiui būtino išsilavinimo ar pakankamos reguliaraus karo patirties. Partizaninių partijų reidai ir laimėti nedideli susidūrimai negalèjo kompensuoti šio trūkumo, todèl etmonai, iki $1764 \mathrm{~m}$. turèję didelę valdžią kariuomenei, nebuvo pajègūs tinkamai organizuoti kariuomenès rengimo. Pradmenys, gauti namų mokyklose ar universitetuose, perskaityta viena kita knygele, šiokios tokios žinios iš fortifikacijos ir artilerijos, medžioklès patyrimas, fechtavimo pratimai ir sveika nuovoka buvo vieninteliai etmonų ginklai, kurių užteko etmonui susikurti savo laikyseną, pasakyti kalbą Seime ar kitokioje garbingoje draugijoje. Toks etmonas geriausiu atveju galèjo imtis veiklos, kokią civilis supranta kaip reikalingą kariuomenès kokybei pagerinti: užtikrinti kariuomenès egzistenciją, pagerinti jos buitį, aprūpinti ginklais ir uniformomis, siekti didesnès tvarkos, drausmès ir visų nurodymų laikymosi. Būtent tokia linkme ir buvo vystoma LDK karo komisija, vadovaujama būsimojo etmono M. K. Oginskio ${ }^{3}$. Tuo tarpu kariuomenès rengimo reguliaraus karo veiksmams praktiškai nebuvo: kariuomenès persirikiavimas iš žygio kolonos ị kovinę rikiuotę, šaudymas divizionais ir visa linija, kariuomenès rūšių sąveika, menas įveikti kliūtis, avangardinè ir ariergardinė kova - visa tai buvo dalykai, kurių Lietuvos kariuomenè ne tik kad nemokejo, bet net nebuvo žinoma, kad to reikia. Teorinių darbų leidimas kaip tik prasidejo Baro konfederacijos metais; mes iki šiol nežinome, kuo naudojosi karininkai rengdami savo kareivius, ar iš viso jie buvo rengiami, nes kariuomenès patikrinimų metu apie tai niekas neklausdavo. Vienintelis $1765 \mathrm{~m}$. instrukcijoje duotas klausimas, nors kiek susijęs su koviniu parengimu, buvo toks: ar daliniuose atliekamos šaudymo pratybos ${ }^{4}$. Be kovinio parengimo daliniuose, be dalinių manevravimo didesniais junginiais, be patirties, igautos ilgesnį laiką lauke vadovaujant didesnèms pajègoms, joks, net ir pats gabiausias vadas, nesugebètų atsilaikyti, kontraatakuoti ar pereiti ị puolimą. Didysis etmonas Mykolas Kazimieras Oginskis tikrai nebuvo blogas etmonas. Jo vykdyti kariuomenès būklès gerinimo darbai (bandymas ịgyvendinti 1766 m. Seimo sprendimą padidinti algas, siunčiant papildomus paaiškinamuosius raštus ${ }^{5}$, inspiruota leidybinè veikla: išleistas kavalerijos reguliaminas ir

\footnotetext{
${ }^{3}$ Plačiau apie LDK Karo komisijos veiklą jau rašyta: Rakutis V. Lietuvos Didžiosios kunigaikštystès karo komisija1765-1776 m.// Karo archyvas, t. XV, Vilnius, 1998.

${ }^{4} 17650809$ Regula lustracyi Ichmc Panom Lustratorom Regimentów przepisana. LVIA, f. SA, b. $18249,1.26-27$.

517681231 įsakymas tautinès kavalerijos divizijoms. Priešakinès sargybos pulkininkui Baranovskiui ir kitiems liepta sustiprinti iždo apsaugą, jei bus išmokètos padidintos algos. LVIA, f. SA, b. $18253,1.73,74$.
} 
rikiuotès forma pėstininkams lenkų kalba ${ }^{6}$, bandymai pagerinti materialini kavalerijos regimentų aprūpinimą ${ }^{7}$ ir asmeninis indẻlis) rodė nuoširdų rūpinimąsi kariuomenès poreikiais, tačiau lauko kautynèse jis buvo niekas palyginus su Rusijos kariuomenès karininkais, kurių bent jau dalis iškilo karų metu, turèjo supratimą apie karą ir reikiamu momentu visada išgelbėdavo Rusijos imperiją. Labai neteisingas, nors amžininkų ir pamėgtas stereotipas, kad etmonas Oginskis buvo muzikas - ne karys, neišlaiko logikos kritikos: muzika visai netrukde karybai. Svarbiausias etmono rūpestis pirmaisiais Baro konfederacijos veiklos metais buvo atgauti etmonų teises, kurios buvo apribotos $1764 \mathrm{~m}$. reformos metu, etmonas nedalyvavo senato posėdžiuose, susirašinèjo su ịvairias vidaus ir užsienio partneriais. Tai, kad Prancūzija galų gale pažadejo konfederacijos pergalès atveju grąžinti senąsias etmonų prerogatyvas, turejjo didelę reikšmę etmono laikysenai ${ }^{8}$. Mykolas Kazimieras Oginskis iki $1771 \mathrm{~m}$. sugebejo savo vertę rodyti tiek draugams, tiek priešams,- jam trūko tik asmeninès šilumos, drąsos ir stipresnio charakterio, bet tokiomis savybėmis retai pasižymi žmonès, kurių karjera daugiau rūpinasi jų aplinka nei jie patys. Šio žmogaus biografijoje dar nèra ištyrinèta ir daugelis jo asmenybės bruožų dar nėra tinkamai atskleisti.

Lauko etmonas J. Sapiega buvo visos veiklos nuošalyje - nei padėdamas, nei trukdydamas Oginskio veiklai. Tik po Stolovičių katastrofos jis perėmè vadovavimą Karo komisijai, siekdamas apsaugoti LDK kariuomenę nuo išformavimo ar finansinio bado.

Saksų laikais nusistovejo tradicija palyginus lengvai dalinti generolų laipsnius, ypač titulinius. Iš tikrujų Lietuvos kariuomenèje buvo tik keturios generolų pareigybès: artilerijos generolo, dviejų generolų leitenantų ir generolo majoro, prie kurių dar galima priskirti tris tautinès kavalerijos regimentorius, tačiau generolo laipsnius praktiškai turejjo visi svetimšalių regimentų pulkininkai ir šefai, o kiek dar buvo titulinių žmonių, negaunančių algos, gali pasakyti tik išsamus ir daug laiko trunkantis valstybinių institucijų ir privačiu archyvų tyrimas. Oficiali sistema buvo taip iškreipta, kad net ka-

\footnotetext{
6 Apie minètą reguliaminą kavalerijai turime tik užuominas karo komisijos dokumentuose: 17680624 įsakymas LB raitelių regimento pulkininkui Radvilai rūpintis karių rengimu pagal lenkišką reguliaminą, išduotą Pinsko raitelių regimentui. Taip pat minima rikiuotès muštro forma (sposób musztrowania po polsku), išduota DB péstininkų pulkui LVIA, f. SA, b. 18253, 1. 64-66.

717690111 įsakymai raitelių regimentų vadams, duodant papildomus pinigus žirgų pagerinimui. LVIA, f. SA, b. 18253, 1. 99-100.

${ }^{8}$ Michalski J. Mykolas Kazimieras Oginskis //PSB TXXIII, 1978, s. 625.
} 
riuomenès daliniams tikrinti nepavyko tų generolų prisišaukti, teko kviestis vidutinès grandies karininkus, turinčius didesnès praktikos ir motyvacijos darbui atlikti. Tik keletas generolų kaip nors pasirodẻ kariniuose veiksmuose: LDK konfederacijos maršalas gen. ltn. Pacas, valdovo pusejje kovoję art. gen. Pranciškus Ksaveras Branickis ${ }^{9}$, gen. mjr. Jonas Jurgis Grabovskis, gen. mjr. Mykolas Grigalius Grabovskis ${ }^{10}$, bet ir tai dažniausiai ne dèl savo pozicijos kariuomenèje, o dèl politinio patikimumo. Geriausiai karo veiksmuose pasirodė Radvilų milicijos plk. Schutzas ir senosios partijų taktikos tęsėjas Simonas Kosakovskis. Lietuvos kariuomeneje, likusioje etmono Oginskio pavaldume, nebuvo nè vieno generolo, kuris būtų sugebejjęs tinkamai parengti dalinius reguliariam mūšiui ir jam vadovauti.

Vidutinių ir jaunesniųjų karininkų korpusas yra dar mažai tyrinėtas ${ }^{11}$, todèl platesnių apibendrinimų reikètų vengti.

Tautinès kavalerijos vẻliavos atrodè pakankamai mažai susijusios.

\section{Lietuvos kariuomenės laikysena $1768 \mathrm{~m}$. kampanijoje}

Pirmosios žinios apie $1768 \mathrm{~m}$. vasario 29 d. paskelbtą Baro konfederacijos manifestą Lietuvą pasiekè maždaug po trijų savaičių, apie kovo 20 dieną $^{12}$. Politiné Lietuvos vaivadijų ir pavietų laikysena buvo atsargi ir tiesiogiai priklausė nuo Vilniaus vaivados Karolio Stanislovo Radvilos, kuris, taip neseniai atgavęs savo valdas iš Rusijos rankų, kaip Radomo konfederacijos maršalas, taip pat neskubejo rodytis kaip maištininkas ir žaide dvigubą žaidimą: prieš vietinius bajorus atlikdamas Saksų dinastijos šalininko ir žmogaus, pasiruošusio imtis atsakomybès už valstybinius LDK interesus, vaidmeni, prieš rusus išlaikydamas ištikimo Imperatorès draugo veidą, tačiau aktyviai tyrẻ situaciją, rinko informaciją ir stiprino savo privatų karinị kompleksą, gerokai nusilpusị per kelerius priverstinos šeimininko emigracijos metus. Jo

\footnotetext{
${ }^{9}$ Pranciškus Ksaveras Branickis - Septynerių metų kare dalyvavęs avantiūristiškais nuotykiais pasižymėjęs Stanislovo Augusto šalininkas, už savo asmenines paslaugas valdovui 17641217 gavęs generolo leitenanto laipsni, o karūnaciniame seime ir LDK artilerijos generolo pareigas, nors buvo nominuotas artilerijos generolu tik 1768 metais. Stanislovo Augusto aplinkoje tikriausiai didžiausius karinius sugebėjimus turèjęs generolas. PSB, t. II, 1936, s. 398.

10 Grabovskių gimine, kaip protestantai, dalyvavo 1767 metų Radomo-Slucko konfederacijos darbe ir kaip vadinamieji disidentai rèmé rusų ir prūsų interesus Respublikoje.

${ }^{11}$ Plačiau apie karininkų korpusą šiek tiek rašyta: Rakutis V. LDK karininkai 1764-1788 metais. Darbai ir dienos, Nr. 5(14), Kaunas, 1997, p. 207-214.

12 Dolinskas V. Simonas Kosakovskis. Politinė ir karinè veikla Lietuvos Didžiojoje Kunigaikštysteje 1763-1794. Vilnius, 2003, p. 163.
} 
situaciją sunkino iki galo neišspręsti turtiniai klausimai, tuo metu sprendžiami rusų pasiuntinio Nikolajaus Repnino įtakoje esančioje komisijoje. Tuo pačiu metu prie Baro konfederacijos organizavimo prisidejo ir buvęs Radomo konfederacijos pasiuntinys Peterburge, Kauno pataurininkas Simonas Kosakovskis, nusprendęs sukelti konfederacinị judejjimą Lietuvoje. Jo veiklos centru pradžioje buvo Vilnius, vẻliau Jonava. Jau liepos viduryje arba pabaigoje susidare 30 raitelių būrys ${ }^{13}$. Prie konfederatų organizacijos prisidejo Kauno pavieto pakamaris Domininkas Medekša, turintis partizaninio karo patirties iš 1734-1735 m. vidaus kovų, ir LDK kariuomenès priešakinès sargybos rotmistras Steponas Šveikauskas (Szwykowski vel Szweykowski) ${ }^{14}$. Kartu su tèvu prie konfederacijos prisidejjo jo jaunas sūnus Teodoras Medekša, baigęs Varšuvos kadetų korpusą, turẻjęs leitenanto laipsnị. Lietuvos kariuomenejje tarnavo ir daugiau konfederacijos vadovų giminių: Simono Kosakovskio brolis, gimęs 1733 m., leitenanto pareigas ėjęs nuo 1759 m., Baro konfederacijos kovų metu vadovavęs Žemaitijos divizijai, yra minimas kaip Kauno partijos arba divizijos regimentorius 1771 m. ${ }^{15}$; Stepono Švetkausko giminaitis Ignas Šveikovski, tuo metu jau $37 \mathrm{~m}$. tarnavęs kariuomenèje ${ }^{16}$. Šie žmonès èmėsi organizuoti kariuomenę rinkdami savanorius ir siūdami uniformas Žeimiuose ir Jonavoje. Kauno pavieto konfederacijos manifeste nèra minima LDK kariuomené, o D. Medekšos paskelbtame universale broliai raginami stoti į kovą su savo dvarų milicijomis. Kariniu besikuriančios konfederacijos vadu ir regimentoriumi tapo Simonas Kosakovskis. Pradžioje kuriama kariuomenẻ buvo sudaryta iš ginkluotų bajorų, dvaro šaulių ir šakèmis ginkluotų valstiečių ${ }^{17}$. Beveik visi ankstyvieji konfederatai buvo seni Radvilų klientai, organiškai sudarę politinị - socialini pažįstamų, giminių ir klientinių hierarchijų bloką. Vèliau buvo siekiama kiekvienam prie konfederacijos prisidejusiam pavietui suformuoti po 100 žirgų kavalerijos vèliavą ${ }^{18}$. Konfederatai, prijungę Ukmergés ir Upytės pavietų pajėgas, pabandè perkelti organizaciją į Žemaitiją, buvo sumušti prie Ariogalos, vèliau, slapstydamiesi Panemunès miškuose ir Prūsijos teritorijoje, laukẻ patogaus

13 Dolinskas V. Simonas Kosakovskis. Politinè ir karinè veikla Lietuvos Didžiojoje Kunigaikštystèje 1763-1794. Vilnius, 2003, p. 170.

14 Dolinskas V. Simonas Kosakovskis... p. 171

15 Oficerowie Rzeczypospolitej... t. II, s. 75.

161777 metais šis karininkas ejo pareigas generaliniame štabe stanowniczy. Oficerowie Rzeczypospolitej... t. II, s. 33.

17 Dolinskas V. Simonas Kosakovskis..., p. 179.

18 Ten pat, p. 182. 
momento. Bandymas vèl ịsijungti ị kovinius veiksmus baigèsi tragiškai, spalio 29 d. patyrus pralaimejjimą prie Višakio Rūdos, po kurio dar kartą buvo pasitraukta ị Prūsiją.

Karolis Stanislovas Radvila, prispaustas Rusijos pajëgų, buvo priverstas kapituliuoti spalio 29 d., taip sugriaudamas daugumos ji palaikiusiųjų viltis. Taigi $1768 \mathrm{~m}$. spalio $29 \mathrm{~d}$. kovos veiksmai buvo baigti.

Šie įvykiai paskatino ir Stanislovą Augustą Poniatovski jau liepos antroje pusejje paraginti savuosius šalininkus nesnausti ir imtis priemonių prieš rengiamą sukilimą ${ }^{19}$. Politinis Stanislovą Augustą Poniatovskị remiantis blokas nebuvo labai gausus, bet pakankamai pajègus. Centrinè šio bloko figūra buvo etmonas Mykolas Kazimieras Oginskis, LDK raštininkas J. Sosnovskis bei Žemaitijos seniūnas J. M. Chodkevičius, o jẻga, palaikanti šiokią tokią valdovo įtaką ir bendrą stabilumą - LDK kariuomenè. Tačiau dar patikimesnè karine jėga buvo gen. ltn. Nummerso vadovaujamas 6000 karių Rusijos kariuomenès korpusas, dislokuotas Lietuvoje dar nuo paskutinès elekcijos laikų, kuris kovą su pirmaisiais konfederatais pradejjo tiems tik pradejjus kurtis, dar 1768 m. rugpjūčio mèn. Rusai buvo dislokuoti Vilniuje, Kaune, Gardine, Pinske, Slonime, gen. Itn. Nummersui pavaldūs buvo gen. mjr. Izmailovas (štabas Gardine) ir gen. mjr. Prozorovskis (štabas Pinske) ${ }^{20}$.

LDK artilerijos generolas Pranciškus Ksaveras Branickis, kaip labiausiai karinius reikalus išmanęs Stanislovo Augusto aplinko žmogus, siekė aktyviais veiksmais užsitikrinti etmono pareigas, todẻl stengèsi susigrumti su konfederacijos kariais kaip galima greičiau. Tokią jo laikyseną sąlygojo ir noras turèti gausesnę kariuomenę, kurią tikèjosi papildyti iš konfederatų perimdamas reguliariosios kariuomenès dalinius ${ }^{21}$. Jau 1768 m. gegužès mèn. jis išvyko i Ukrainą. Birželio mèn. teturèjo 400 karių, tarp kurių būta ir LDK kariuomenès karių iš A. M. Koryckio totorių pulko. Lietuvos totoriai dalyvavo artilerijos generolo P. K. Branickio kampanijoje Podoleje, kurios metu pats pulkininkas Koryckis ties Zinkovcais savo pulko avangardo priešakyje sumušè Jozefo Slavoševskio partiją, birželio 10 d. dalyvavo sèkmingame konfederatu „lizdo“ Baro tvirtovès šturme ${ }^{22}$, vèliau priklausẻ kordonui ties Dniestru, kuris saugojo, kad konfederatai negalètų grịžti ị Respublikos teritoriją. Spalio ir

\footnotetext{
${ }^{19}$ Konopczyński W. Konfederacja Barska, Warszawa, 1936, s. 89

20 Ten pat, s. 90 .

21 Gumplowicz L. Korespondencja między Stanisławem Augustem aa Ksawerym Branickim, lowczym korronnym w roku 1768. Kraków, 1872, s. IV-V.

22 Szczygielski W. Korycki Aleksander Mustafa. PSB, T. XIV, 1968-1969, s. 136.
} 
lapkričio mėnesiais dalyvavo artilerijos generolo P. K. Branickio organizuotoje politineje misijoje pas Chocimo pašą, kur siekẻ užmegzti draugiškus santykius bei trukdyti konfederatų pastangoms ịtraukti Turkiją i karą. Gruodžio mẻnesį totoriai grịžo ị savo dislokacijos vietą Bresto vaivadijoje ${ }^{23}$.

Lietuvos kariuomenès pradiniame konfederacijos kūrimosi etape tarsi nebuvo, turime tik keletą duomenų apie bandymus patraukti ị savo pusę karinius dalinius: Lietuvos Kamenece buvo kuriam laikui jungtos kelios kavalerijos vẻliavos, atimta LDK gvardijos raitelių leibregimento kasa Pružanuose (130 000 auksinų) bei sujungtas pats leibregimentas, kuriame buvo daugiau nei šimtas žmonių. Vèliau šis dalinys buvo perimtas rusų kariuomenės, už pasyvią laikyseną konfederatų atžvilgiu buvo nužudytas senas generolas Petersonas ir kai kurie kiti karininkai. Repnino ataskaitoje minima, kad i konfederatų pusę lengvai perẻję regimentai nustojo egzistuoti, t. y. išformuoti ${ }^{24}$. Taip pat sąlyginiais LDK kariuomenès atstovais buvo konfederatų pusẻje veikę atskiri asmenys, kai kurie turẻję aukštus laipsnius, pavyzdžiui, Ziolovo seniūnas gen. Itn. M. J. Pacas ${ }^{25}$, tačiau tokių titulinių generolų Lietuvoje buvo ne vienas ir jokiais saitais su kariuomene jie nebuvo susieti. Rezervuota Lietuvos kariuomenès vadų, kaip ir kitų didikų, pozicija galẻjo būti aiškinama ne tik „rusiškuoju oportunizmu“, t. y. Rusijos jẻgos pripažinimu ir vengimo tiesioginès kovos su ja ${ }^{26}$, bet ir teisingu situacijos vertinimu: bet koks sukilimas prieš Rusiją be politinès kitų valstybių pagalbos, ypač suskaidžius krašto jègas, negalèjo duoti jokių rezultatų. Taip pat didelę reikšmę turejjo Karolio Stanislovo Radvilos laikysena: po ilgų svarstymų ir gąsdinimų Nesvyžiaus ir Slucko tvirtovès įsileido rusus ${ }^{27}$.

\section{1769-1770 m. kampanijos}

1769 m. birželio vid. konfederacijos iniciatorių Pranciškaus ir Kazimiero Pulaskių pajẻgos ịsiveržè i Lietuvą ir pabande sukelti čia konfederacijai palankų sukilimą. Pirmiausiai jie pasistengè ì savo pusę patraukti totorių pulkus. Karaliui ištikimi totoriai neskubejo pulti stačia galva ị konfederatu glèbị, bet argumentas, kad musulmonams netinka kovoti prieš partiją, kurią

\footnotetext{
23 Ten pat.

24 Konopczyński W. Konfederacja Barska, Warszawa, 1936, s. 97-98.

25 Dolinskas V. Simonas Kosakovskis... , p. 190

26 Ten pat, p. 205.

27 Konopczyński W. Konfederacja Barska, Warszawa, 1936, s. 103-105.
} 
remia Turkijos valdovas, juos įtikino. Koryckio pulkas, stovėjęs Sucha Vola miestelyje, ir Bielako pulkas, stovejjęs Lomazuose, perẻjo ị Pulaskių pajègų pusę ir aktyviai dalyvavo vasaros kampanijoje, tarp Bžostovicų ir Krynkų išvaikydamas kazokų padalinius, puikiai kovèsi ties Kukielkomis (liepos 6 d.), Slonimu (liepos 12 d.), Jakimovičiais ( liepos 13 d.) ir Molčadžia (liepos 16d.). Liepos ir rugpjūčio sandūroje dengè Lietuvos generalinès konfederacijos organizavimąsi, susirinkusią Reigarde. Susikūrusi generalinè konfederacija atsisakè veikti kartu su Pulaskiais, o abu totorių pulkus perėmė savo žinion, tačiau Rusijos generolo Drevico pajẻgos privertẻ nepakankamai sustiprejusias konfederatų pajëgas trauktis link Prūsijos sienos. Totoriai dalyvavo ariergardiniame mūšyje ties Nemunaičiu ir vẻliau mūšyje ties Jurbarku ${ }^{28}$.

Prie Nemuno rugpjūčio $5 \mathrm{~d}$. vykusiame mūšyje dalyvavo apie 4 tūkstančius karių turinčios konfederacijos pajègos ir rusų pajëgos, kurias sudarẻ Drevico grupuote iš Prienų su 800 karių ir Gardino grupuote, iš viso 2 tūkstančiai karių. Konfederatai buvo prie Virbalio, rusai prie Pilviškio, taigi sugebėjo įspausti konfederatus ị aklavietę, kurią sudarẻ Nemunas ir Prūsijos siena. Konfederatai, turẻdami karių persvarą, nusprendè stoti ị kovą ir išsirikiavo mūšiui, tačiau netikètai buvo išduotos savo vadų, maršalo Ziolovo seniūno Paco ir regimentoriaus Sapiegos. Nepaisant tokios išdavystès, konfederatai stojo ị kovą, bet patyre didelių nuostolių ir buvo dezorganizuotos i atskirus padalinius, kas pasitraukè į Prūsiją, kas ị Palenkę. Be minètų totorių pulkų, į konfederatų pusę buvo įtraukta Jurbarko tautinès kavalerijos vẻlia$\mathrm{va}^{29}$. Bielako ir Koryckio pulkai po kelių susidūrimų pasitraukè ị pietus, kur rugpjūčio $10 \mathrm{~d}$. paskelbė grịžtą ị Lietuvos karo komisijos pavaldumą, rugsẻjo 1 d. davė priesaiką valdovui Stanislovui Augustui Varšuvoje ir grị̌zo ị dislokacijos vietas, nors Pulaskiai vèl bandè į savo pusę juos patraukti ${ }^{30}$.

Šiaulių ekonomijos sukilimas arba maištas prieš Antano Tyzenhauzo vykdomą prievolių sunkinimą tapo dar viena prievole Lietuvos kariuomenei. 1769 m. gruodžio 23 d. Karo komisija prisidèjo prie karaliaus 1769 m. gruodžio 20 d. nurodymo malšinti neramumus Šiaulių ekonomijoje.

$1770 \mathrm{~m}$. buvo ramūs, kovos veiksmai LDK teritorijoje nevyko, todèl Lietuvos kariuomené vykdè ịprastas savo funkcijas. Dar 1770 m. sausio mèn. ì

\footnotetext{
${ }^{28}$ Kryczyński S. Bielak Józef. PSB, T. II, Kraków, 1936, s. 32-33; Szczygielski W. Korycki Aleksander Mustafa. PSB, T. XIV, 1968-1969, s. 136.

${ }^{29}$ Rugpjūčio 9 dieną vykusio mūšio prie Tauragès aprašymas. LNMB, RS, F99-1827. Mūšis bibliotekoje neteisingai datuotas 1770 metais.

${ }^{30}$ Kryczyński S. Bielak Józef. PSB, T. II, Kraków, 1936, s. 32-33; Szczygielski W. Korycki Aleksander Mustafa. PSB, T. XIV, 1968-1969, s. 136.
} 
Šiaulių ekonomiją buvo pasiųstas vèliavininkas Jonas Truškovskis (Jan Truszkowski) su rinktine komanda iš visų Žemaičių divizijos kavalerijos vèliavų (po draugą arba vietininką ir 5-15 eilinių nuo vèliavos), kuri visa nesusirinko ir jos dydis nežinomas ${ }^{31}$.

Kariuomenès dydis tuo metu sunkiai skaičiuojamas: Žemaičiu divizijai priklausančiose 3 husarų ir 7 petihorų vẻliavose buvo 344 kariai, gavę 506 žirgų porcijas, iš jų 143 poros draugų ir eilinių ${ }^{32}$. DB raitelių regimentą, be štabo, metų pradžioje sudarė apie $130 \mathrm{kariụ}^{33}$. Etmonas M. K. Oginskis liepos mėnesį atskirą įsakymą skyrė savojo Didžiosios buožės raitelių regimento žirgu problemoms, liepdamas iki žiemos aprūpinti karius žirgais, stengiantis kariams skirti šyvus, o jaunesniajam štabui ir muzikantams juodus žirgus. Netinkamus žirgus reikẻjo parduoti arba iškeisti. İsakymo parašymo dieną regimente buvo tik 60 žirgų; buvo siekiama jų skaičių padidinti iki 70 , siunčiant veliavininką Rozenbaumąa ${ }^{34}$. Dalinyje buvo tik dalis kareivių, ju skaičiu buvo norèta padidinti iki 150, taigi etatinio dydžio, matyt, tuo metu nesiekè ir kiti raitieji regimentai.

1770 m. vasario mèn. Koryckio pulkas, būdamas valdovui ištikimų P. K. Branickio dalinių sudètyje, vèl kovėsi prieš konfederatus ir daugiausiai būtent Lietuvos totorių pastangomis buvo sumuštas Jano Bachovskio dalinys tarp Bresto ir Miedzyžečo. Spalio mènesị buvo suduotas didelis smūgis konfederatų daliniams Žerčychuose Palenkèje ${ }^{35}$. Spalio - lapkričio mėnesių sandūroje Koryckio pulkas trumpam buvo patekęs ị konfederatu vado Bresto maršalo O. G. Benklevskio pavaldumą, tačiau sugebejjo pasitraukti ị saugesnę vietą užklupus rusams. Ramybè truko neilgai, užgriuvus konfederatų jëgoms: Koryckio pulkas kovėsi su Jozefu Sava Calinskiu (du kartus ties Vkra prie Stregovo, lapkričio 9 d. prie Pultusko ir gruodžio 17 d. vèl su Galinskiu). Po šių kovų, kuomet pulkas patyrè nuostolių, o pats A. M. Koryckis buvo sužeistas, pulkas pasitraukè ị savo dislokacijos vietą Bresto vaivadijoje.

\footnotetext{
3117700108 Žemaitijos divizijos raportas, pasirašytas regimentoriaus Mykolo Korvino Kosakovskio. LVIA, f. SA, b. 18255, 1. 12.

3217700108 Žemaitijos divizijos raportas, pasirašytas regimentoriaus Mykolo Korvino Kosakovskio. LVIA, f. SA, b. 18255, 1. 5-7.

331770 m. pradžios DB Raitelių regimento karių komandiruočių sąrašas. LVIA, f. SA, b. 18255, 1. $30-32$.

3417700716 Etmono M. K. Oginskio ịsakymas vèliavininkui Rozenbaumui. LVIA, f. SA, b. 18255, 1. 44.

35 Szczygielski W. Korycki Aleksander Mustafa. PSB, T. XIV, 1968-1969, s. 137.
} 
1770-1771 m. Lietuvos kariuomenès vadovybė jau vedė slaptas derybas su Baro konfederatais dèl galimo prisidèjimo prie šio judejjimo. Tuo metu didelę îtaką konfederacijai darè Prancūzijos emisaras pulkininkas Diumurjè (Dumouriez). Šis karininkas turejo kiek galima labiau sustiprinti silpną konfederacijos centrinę valdžią, parengti konfederacijos veikimo bazę, sudarytą iš tvirtovių, ir parengti reguliarios kariuomenès branduolį, kuri ilgainiui galètų kovoti atvirame lauke. Šiam reikalui iš Prancūzijos pasiųsti karininkai ir puskarininkiai, pinigų, suteikta diplomatine pagalba. Visiems šiems darbams atlikti reikejjo laimėti šiek tiek laiko, todẻl buvo nuspręsta atlikti dẻmesi nukreipiantị manevrą organizuojant stambios divizijos ir nedidelio kavalerijos dalinio įsiveržimą i Rusijos kariuomenès užnugarị bendra kryptimi link Maskvos. Ši manevrą, anot Diumurjè, turejjo atlikti 8000 žmonių divizija, sudaryta iš reguliarios Lietuvos kariuomenès, vadovaujamos etmono M. K. Oginskio, Bieliako ir Koryckio totorių pulkų ir visuotinio lietuvių šaukimo bei atskirai veikianti Pulaskio partija Podoleje. Pradžioje šie daliniai turejjo imituoti puolimą Varšuvos link, bet paskui vykdyti tikraji puolimą ${ }^{36}$.

\section{4. $1771 \mathrm{~m}$.}

Lietuvos kariuomenès koncentracija buvo vykdoma sanitarinio kordono prieš plintančią epidemiją pretekstu. Jau 1770 m. gruodžio 10 d. buvo liepta suformuoti ši kordoną prieš marą, jam vadovauti paskirtas pats etmonas Oginskis, kuris igaliojo vietoje vadovauti DB raitelių pulko plk. Itn. Jurgi Haudringą ${ }^{37}$. Jau vasario $20 \mathrm{~d}$. kordonas buvo suformuotas ir nedidelèmis komandomis išdėstytas ties Lenkijos - Lietuvos siena. Birželio $1 \mathrm{~d}$. šią jungtinę komandą sudaré po vieną kuopą iš lauko buožès péstininkų, lauko buožès raitelių, generolo Grabovskio raitelių regimentų ir artilerijos freikompanijos, iš viso 191 svetimšalių autoramento karys ir po vieną vẻliavą iš Bieliako, Koryckio ir lauko buožės priešakinės sargybos pulkų, iš viso 158 raiteliai, 349 karių komanda, vadovaujama plk. ltn. Jurgio Haudringo iš Chomsko ${ }^{38}$. Komanda turejo susirinkti vasario $22 \mathrm{~d}$. tame pačiame Chomske.

Birželio 17 d. Karo komisija etmonui Oginskiui leido reikalui esant kilnoti ar surinkti dalinius, jei to reikalautų jų saugumas, taigi etmonas iga-

\footnotetext{
${ }^{36}$ Dumouriez. Wojna w Polsce 1770 i 1771 r. Z pamiętników Generała Dumourieza.//Pamiętniki z ośmnastego wieku, t. VI,

3717701222 Karo komisijos sprendimas. LVIA, f. SA, b. 18252, 1. 15

38177106 01Komandiruotų kordonui sudaryti karių lentelè. LVIA, f. SA, b. 18255, 1. 117.
} 
vo juridines teises laisvai disponuoti LDK kariuomene tarp Karo komisijos posėdžių ${ }^{39}$. Siekdamas apsaugoti LDK kariuomenès dalinius nuo pavojingų operacijų Branickio dalinių sudetyje, Oginskis išgavo LDK karo komisijos nutarimą nesiųsti daugiau Lietuvos karių į Karūnos kovas, tačiau A. M. Koryckio pulkas vėl buvo panaudotas Branickio kovose ir birželio 23 d. prie Vidavos totorių pulkas buvo sumuštas J. Zarembos pajėgų: 80 karių ir pats A. M. Koryckis buvo paimti į nelaisvę, bet greitai paleisti ${ }^{40}$. Tuo pačiu metu generolo Bielako pulkas gavo etmono Oginskio ịsakymą vykti ị Chomską, dẻl ko sunerimo valdovas, pasiuntęs laišką Karo komisijai dar 1771 m. birželio 5 d., bei Rusijos ambasadorius Saldernas, siuntęs brutalius ir žeminančius isakmaus tono laiškus ${ }^{41}$.

Simono Kosakovskio reido metu ị sumaištị papuole penkios Žemaitijos divizijos vẻliavos, tarp jų ir Trakų vaivados Oginskio petihorų vẻliava ${ }^{42}$. Užèmus vèliavą buvo paimti eiliniai kariai su ginklais, žirgais ir uniformomis bei pinigais, kuriuos konfederatai birželio 5-7 d. nusivedẻ su savimi. Jau pačiomis pirmomis dienomis rusai tai numate ir miške ties Naujamiesčiu atakavo: iš vèliavos 5 žuvo, trys grižzo, tik vienas su žirgu, vienas karys dingo be žinios ${ }^{43}$. Ši faktų informacija rodo, kad netikètai užpuolus vėliavoje nebuvo nei karininkų, nei draugų, tik eiliniai, vadovaujami vieno draugo-vietininko.

Etmono deklaracijoje, sudarytoje $1771 \mathrm{~m}$. rugsejjo $7 \mathrm{~d}$. Chomske, buvo deklaruota, kokiu teisiniu pagrindu Lietuvos etmonas pradejjo kovą. Jis pasirèmé sena etmonų teise ,ižzengus svetimai kariuomenei ị kraštą Respublikos kariuomenę rinkti“", neteisètai atimta etmonų valdžia ir tuo, kad Rusijos pasiuntinys ir jo generolai bandè tiesiogiai vadovauti Lietuvos kariuomenès daliniams ir kad Rusijos pulkininkas etmonui ịsakymus davinẻja. Nutarimą prièmè kartu su Karo komisijos komisarais vienbalsiai. Net keliose vietose prašè Generalinès konfederacijos atleisti už vẻlyvą prisidẻjimą ${ }^{44}$. Rašte neužsimenama apie Stanislovą Augustą Poniatovskị, apie kovą su juo, akcentuojama tik kova su Rusija, „svetimšalių kariuomene“. Tokia pozicija neuž-

\footnotetext{
3917710617 Karo komisijos. LVIA, f. SA, b. 18252, 1. 16

${ }^{40}$ Kryczyński S. Bielak Józef. PSB, T. II, Kraków, 1936, s. 32-33; Szczygielski W. Korycki Aleksander Mustafa. PSB, T. XIV, 1968-1969, s. 137.

4117710605 laiškas a ministerio karo komisijai. LVIA, f. SA, b. 18252, 1. 18

42 S. Kosakovskiui pavyko paimti Siemeniškių (Pienionių seniūnijoje), Kupiškio, Vabalininko, Užtakio ir minètają Trakų vaivados Papolotuose vẻliavas, kurios buvo prie Naujamiesčio užkluptos ir išvaikytos.

4317710611 petihorų vèliavininko Juozapo de Volda Helmanno raportas. LVIA, f. SA, b. 18255, 1. 141-142.

4417710907 manifestas. NMB RS, f. 99, b. 1814.
} 
kirto kelio ateityje surasti kontaktą su Stanislovu Augustu ir jo aplinka.

I klausimus, kokio dydžio buvo LDK kariuomenè karinès akcijos išvakarèse, kuri kariuomenès dalis dalyvavo akcijoje ir kokius patyrè nuostolius, galima atsakyti tik apytikriai. Didžiosios buožès raitelių regimentas, kurio stiprinimu etmonas ypač rūpinosi dar praeitais metais, buvo visiškai pasirengęs kovai, jame buvo 153 kariai ir 70 žirgų (trūko 80-ties žirgų), 8 karininkais buvo daugiau, nei numatyta etate ${ }^{45}$. Lauko buožès regimente vasaros pradžioje buvo 276 kariai $^{46}$. Pinsko regimente gegužès mėnesị buvo 85 kariai su 20 žirgų, beveiki visi karininkai buvo išsiųsti atostogų ${ }^{47}$. Tribunolo vėliavoje, kuriai vadovavo seržantas, vasaros pradžioje buvo 66 kariai $^{48}$. Didžiosios buožès janyčarų vẻliavoje vasaros pradžioje buvo 4 karininkai, 7 puskarininkiai, felčeris, 17 muzikantų ir 81 kareivis, iš viso 110 karių $^{49}$. Tautinès kavalerijos vèliavų skaičių sunku suskaičiuoti, nes nėra aišku, kiek patikima jų pačių teikiama medžiaga. Visuose raportuose minimi visi žmonès pagal numatytą karių skaičių, tačiau labai abejotina, kad bent pusẻ jų buvo prie vėliavos. Akivaizdu, kad visos kavalerijos vėliavos turëjo rimtų aprūpinimo problemų: dažniausiai žirgų visai nėra arba jie gyvena pas draugus - savininkus, iš ginkluotès visur minimi tik kardai, šautuvų ir pistoletų arba iš viso neturejo, arba jie buvo seni. Uniformą atstojo tik atskiri jos elementai arba senojo modelio uniformos likučiai. Kitaip sakant, tautinès kavalerijos vèliavos buvo tik popieriuje.

\footnotetext{
4517710607 DB dragūnų regimento raportas, LVIA, f. SA, b. 18255, 1. 119.

$4617710601 \mathrm{LB}$ pesstininkų regimento raportas. LVIA, f. SA, b. 18255, 1. 120.

4717710601 gen. mjr. Grabovskio raitelių regimento raportas: 13 žmonių štabe, kuopose po 3 puskarininkius ir 15 kareivių, kiekvienoje kuopoje po 5 žirgus. LVIA, f. SA, b. 18255, l. 122.

4817710601 Vyriausiojo tribunolo vèliavos raportas. LVIA, f. SA, b. 18255, 1. 125.

4917710601 DB janyčarų vèliavos raportas LVIA, f. SA, b. 18255, 1. 120.
} 
2 lentelè. Tautinès kavalerijos vẻliavos $1771 \mathrm{~m}$. gegužès - birželio mèn..$^{50}$

\begin{tabular}{|c|c|c|c|c|c|c|c|c|}
\hline Vèliava & 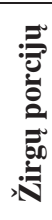 & 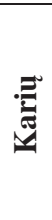 & 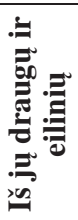 & 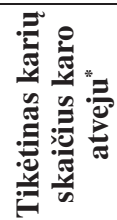 & $\frac{E}{\frac{E}{0}}$ & $\stackrel{\Xi}{\Xi}$ & 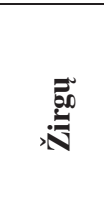 & 苛 \\
\hline $\begin{array}{l}\text { Juozapo } \\
\text { Davainos } \\
\text { Sollohubo } \\
\text { petihoru } \\
\text { vėliava }\end{array}$ & 40 & 21 & 18 & 11 & $\begin{array}{c}\text { Yra, } \\
\text { ne } \\
\text { pagal } \\
\text { mo- } \\
\text { delị }\end{array}$ & $\begin{array}{c}\text { Yra, } \\
\text { ne } \\
\text { pagal } \\
\text { mo- } \\
\text { delị }\end{array}$ & $\begin{array}{c}\text { Eilinių } \\
\text { karių } \\
\text { žirgų } \\
\text { nèra }\end{array}$ & $\begin{array}{c}\text { Yra, } \\
\text { bet ne } \\
\text { pagal } \\
\text { modeli, } \\
\text { trūksta } \\
\text { ele- } \\
\text { mentu }\end{array}$ \\
\hline $\begin{array}{l}\text { Trakų vaiva- } \\
\text { dos Ogins- } \\
\text { kio petihoru } \\
\text { vèliava }\end{array}$ & 40 & 21 & 18 & 11 & $\begin{array}{l}\text { Yra, } \\
\text { vieno- } \\
\text { do ka- } \\
\text { libro }\end{array}$ & $\begin{array}{c}\text { Yra, } \\
\text { vie- } \\
\text { nodo } \\
\text { kali- } \\
\text { bro }\end{array}$ & $\begin{array}{c}\text { Eilinių } \\
\text { karių } \\
\text { žirgai } \\
\text { po } \\
\text { namus } \\
\text { išsiųsti }\end{array}$ & $\begin{array}{c}\text { Yra } \\
\text { pagal } \\
1767 \\
\text { vasario } \\
20 \mathrm{~d} . \\
\text { modeli }\end{array}$ \\
\hline $\begin{array}{l}\text { Žemaičių } \\
\text { seniūno } \\
\text { petihorų } \\
\text { vėliava }\end{array}$ & 40 & 22 & 20 & 12 & $\begin{array}{l}\text { Yra, } \\
\text { seno } \\
\text { pa- } \\
\text { vyz- } \\
\text { džio }\end{array}$ & $\begin{array}{c}\text { Yra, } \\
\text { seno } \\
\text { pavyz- } \\
\text { džio }\end{array}$ & ? & $\begin{array}{c}\text { Yra, } \\
\text { seno } \\
\text { pavyz- } \\
\text { džio, } \\
\text { prancū- } \\
\text { ziškos } \\
\text { medžia- } \\
\text { gos }\end{array}$ \\
\hline $\begin{array}{l}\text { Rečicos } \\
\text { stalininko } \\
\text { Radvilos } \\
\text { petihoru } \\
\text { vèliava }\end{array}$ & 40 & 24 & 20 & 12 & Nèra & Nèra & & $\begin{array}{c}\text { Yra } \\
\text { seno } \\
\text { pavyz- } \\
\text { džio }\end{array}$ \\
\hline $\begin{array}{l}\text { Trakų kaš- } \\
\text { teliono Liu- } \\
\text { dviko Plate- } \\
\text { rio petihoru } \\
\text { veliava }\end{array}$ & 40 & 21 & 18 & 11 & $\begin{array}{c}9 \text { nau- } \\
\text { jos } \\
\text { poros }\end{array}$ & $\begin{array}{c}9 \text { nau- } \\
\text { ji ir } 9 \\
\text { seni }\end{array}$ & $\underset{\text { žirgų }}{\mathrm{Be}}$ & $\begin{array}{c}\text { Nau- } \\
\text { ja, su } \\
\text { tik ką } \\
\text { pada- } \\
\text { rytomis } \\
\text { kepure-- } \\
\text { mis. }\end{array}$ \\
\hline
\end{tabular}

* Tikètiną karių skaičių karo atveju sudaro: draugas - vietininkas, trimitininkas ir eiliniai.

${ }^{50}$ Lentelèje paminètų vèliavų raportai LVIA, f. SA, b. 18255, 1. 135-139. 
Oginskio pajègose buvo ir garsieji Bielako ir Koryckio pulkai ar bent didžioji jų dalis. Koryckio kariai buvo smarkiai nukentėję birželio mėnesio mūšio metu, bet spejo grịžti iš nelaisvès tiesiai i stovyklą prie Telechanų ${ }^{51}$. Pagal įvykio liudininko rotmistro Snarskio parodymus ${ }^{52}$, Lietuvos kariuomenejje buvo apie 3000 karių, o tai iš esmès patvirtina turimus duomenis. Rusu duomenimis, Oginskis turejjo apie 4000 karių $^{53}$, tačiau šių skaičių nepatvirtina archyvinių duomenų analizè.

Pirmuoju Lietuvos kariuomenès ugnies krikštu tapo Bezdzežo mūšis. Kaip galima spręsti iš turimų aprašymų ${ }^{54}$, etmonas Oginskis su surinkta Lietuvos kariuomene (jos dalị sudarè Haudringo kordono bei kiti spèti surinkti daliniai) buvo Chomske, kai jị ėmė supti rusų daliniai: pulkininko Albičevo pulkas, kuriame buvo apie 700 karių, Doringas bei Wangelis. Pulkininkas A. Alabyčevas (Алабычев) turejjo blokuoti brastą ties Bezdzežu, o Doringas su Wangeliu - kitas komunikacijas. Tuo tarpu Oginskis, gavęs ultimatumą, daugiau nedelsė ir demonstracijos tikslais sekmadienį du pulkus pasiuntė kitą Jasioldos upés krantą link Pinos. Jis pats su likusia kariuomene kitą rytą, palikęs sargybą, kuriai liepé nieko neleisti ị savo miestą, su visa gurguole persikèle i kitą Jasioldos upès pusę ir nužygiavo ị Čemeriną, kitą dieną pasiekẻ Oborovą, o trečiadieni Janovą. Tuo metu plk. A. Alabyčevas, siekdamas ketvirtadieni pasiekti Čemerino brastą, netikètai pamaté, kad etmonas jau išžygiavęs, todèl nutarè diplomatinėmis priemonemmis sulaikyti lietuvius (buvo siūloma nusiginkluoti ir grịžti ị Telechanus), kol atvyks pastiprinimas. Etmonas taip pat siekẻ laimèti laiko, bet ne stovèti, o greitam manevrui parengti, todèl pareikalavo iš pulkininko raštiško igaliojimų patvirtinimo, o pats tuo metu, 5 dienos vakare, slaptai paliko stovyklą ir kitąryt 10 valandą jau rikiavo savo karius Bezdzežo igulos šturmui. Rusai pamatė išsirikiavusią lietuvių pirmają liniją tik per patrankos šūvio nuotolị. Dabar jau etmonas du kartus pasiuntė bunčiukininką, siūlydamas pulkininkui Alabyčevui pasiduoti aptartomis sąlygomis. Gavęs neigiamą atsakymą, etmonas įsakẻ pul-

\footnotetext{
${ }^{51}$ Kryczyński S. Bielak Józef. PSB, T. II, Kraków, 1936, s. 32-33; Szczygielski W. Korycki Aleksander Mustafa. PSB, T. XIV, 1968-1969, s. 137.

52 Opisanie nieszczęsliwej klęski przez wojsko Litewskie poniesionej pod Stolowiczami Ru 1771 w Nowogrodzkiem MAB RS f. 18-206/1, p. 187-189.

${ }^{53}$ Komentarai Suvorovo 17710914 laiškui gen. M. N. Krečetnikovui. //Суворов А. Письма. Москва, 1987, с. 488.

54 Działania Hetmana Ogińskiego. Wiadomość o akcyi dnia 6 Septembris 1771 Roku zaszłej między wojskiem W, Ks. Litewskiego a Rosjanami pod Antopolem przez naocznego świadka Rotmistrza kawaleryi Narodowej Jana Snarskiego adnotata MAB RS f. 18-206/1, p. 183-186.
} 
ti. Kadangi miestelio prieigos buvo netinkamos linijinei atakai, pabūklams buvo liepta apšaudyti malūną ir siaurumą, tuo tarpu buvo suformuotos kelios šturmo grupés, turëjusios iš visų pusių atakuoti rusus. Du eskadronai, vadovaujami plk. Paškovskio, du, vadovaujami rotmistro Achmatovičiaus, taip pat 30 dragūnų, vadovaujamų plk. ltn. Audringo, su savanoriais iš JKM Baranovskio priešakinès sargybos pulko rotmistro Kričinskio vẻliavos, o kiti raiteliai iš JKM Baranovskio pulko, vadovaujami véliavininko Baranovskio, apejjo poziciją nuo Chomsko pusès. Užpuolus rusus iš visų pusių ir pabūklo sviediniui užmušus pulkininką Alabyčevą, o per siaurumą puolant DB pėstininkų regimento pulkininko leitenanto Paplonskio vyrams, rusai neteko apie pusantro šimto karių ir buvo priversti visu pulku pasiduoti. Nelaisvėn pateko 490 eilinių, 20 puskarininkių ir 16 karininkų kartu su visais ginklais, žirgais ir dviem patrankomis. Tuo metu nuo Bresto atejo 70 karių pagalba, kurią nukovẻ kavalerijos eskadronas, vadovaujamas rotmistro Achmatovičiaus. Karininkai, davę priesaiką daugiau nekovoti prieš konfederatus, buvo paleisti i Brestą, aprūpinti žirgais ir net pinigais. Taip pat buvo paimta pulkininko kanceliarija, kur buvo įsakymai apsupti ir puti Telechanus bei lenkų kalba parengtas reversas, skirtas pasidavusios Lietuvos kariuomenès kariams ${ }^{55}$.

Mūšio analizė rodo, kad Lietuvos artilerija mokèjo pataikyti, o kariuomenè sugebejo apsupti ir sunaikinti kad ir mažesnę, bet reguliarią rusų grupuotę. Atakos metu pagrindinius manevrus vykdè svetimšalių autoramento raiteliai ir totorių vėliavos bei JKM Baranovskio priešakinès sargybos pulko kariai, o frontini puolimą defilè sąlygomis vykdė péstininkai. Svarbu tai, kad visiškai neminimi tautinès kavalerijos kariai.

Po Bezdzežo mūšio LDK kariuomenẻ bande žygiuoti link Nesvyžiaus. Rusai buvo blokavę gerus kelius, todèl iš Pinsko buvo žygiuojama pelkių keliais link Liachovičių, paskui link Klecko, tačiau sužinojus, kad Nesvyžius jau užimtas rusų igulos, buvo pasukta Miro Naugarduko vaivadijos link. Etmono Oginskio planas buvo sumušti priešo korpusus atskirai, siekiant turèti skaičiaus persvarą prieš kiekvieną iš jų, neleisti jiems susijungti. Tuo pačiu metu Rusijos pulkininkas Aleksandras Suvorovas, kurio dalinys buvo dislokuotas Liubline ir gavo tik šalutinius pavedimus, nusprende pasinaudoti, jo nuomone, puikia proga pasidemonstruoti ir, be savo viršininko gen. Veimarno nurodymo ir netgi prieš šio valią, nieko nelaukdamas išžygiavo iš savo

55 Działania Hetmana Ogińskiego. Wiadomość o akcyi dnia 6 Septembris 1771 Roku zaszłej między wojskiem W, Ks. Litewskiego a Rosjanami pod Antopolem przez naocznego świadka Rotmistrza kawaleryi Narodowej Jana Snarskiego adnotata MAB RS f. 18-206/1, p. 183 - 186. 
dislokacijos vietos ir forsuotu maršu pasiekè Brestą, iš kur greitai pasieke Oginskio kariuomenès pozicijas ${ }^{56}$.

Sužinojęs apie generolo A. Suvorovo korpuso, sudaryto iš 500 pėstininkų ir 200 raitelių, dislokaciją Stolovičiuose, etmonas liepė kariuomenei paskubėti ir užklupti juos netikètai, tačiau kai Lietuvos kariai atvyko, Suvorovo kariai jau buvo pasitraukę. Generolas Bielakas su kitais senaisiais kariais siūlèsi persekioti priešą ir išsiaiškinti, kur šis pasitraukè, tačiau Igno Chominskio patartas etmonas įtare totorių išdavystę ir neleido kariams palikti miestelio bei liepe ịsikurti nakčiai, nelabai besirūpinant sargyba. Etmonas manè, kad 700 rusų nedrịs pulti 3000 lietuvių, tuo labiau po laimèto mūšio, todèl pèstininkų sargybos aplink miesteli ne visur buvo pastatytos, priešo persekioti niekas pasiųstas nebuvo, nors generolas Bielakas pats su savo pulku siūlèsi tai padaryti ${ }^{57}$. Kunigas vikaras Znatovičius stengèsi perspėti etmoną apie pavojų, kad rusai gali nakti grịžti, tačiau I. Chominskis, dešinioji etmono ranka, jo neleido pas etmoną, tariamai saugodamas šio miegą. Taigi 3 valandą nakties užpuolę rusai užklupo lietuvius visai nepasiruošusius. Suvorovo rusai ${ }^{58}$ pirmiausiai apšaude kleboniją, kurioje gyveno etmonas, tuo įvarydami jam didelę baimę, po to užpuole etmono bagažą, kasą ir paėmé 10 artilerijos pabūklų ir 40 artilerijos gurguolių su amunicija bei etmono bagažą, kurio tik dalị vẻliau totoriams pavyko atgauti. Visa gynyba buvo deorganizuota. Rusai pagrobė apie 10 milijonų auksinų kasą ${ }^{59}$. Toks tikslus smūgis leistų spèti, kad rusai turejjo išsamią žvalgybos informaciją arba būta išdavikų. Kai kurie karininkai su savo kareiviais bande atsikovoti gurguolę, tačiau juos iš nugaros esą atakavo išdavikai ir jie buvo nukauti. Pagal Oginskio versiją ${ }^{60}$, jis esą dar bande stabdyti bėgančius péstininkus, bet jie jau buvo be ginklų, todèl, liepęs kavalerijai prisidèti prie kokios nors sritinès konfederacijos, patraukẻ Prūsijos sienos link. Ar gavusi ši ịsakymą, ar ne, kavalerija, kurios pagrindą sudarè, kaip galima spèti, Bielako totorių pulkas, saugiai pasitraukè ir išsirikiavusi pasirenge mūšiui, taip pradėdama antrą

\footnotetext{
${ }^{56}$ Komentarai Suvorovo 17710914 laiškui gen. M. N. Krečetnikovui//Суворов А. Письма. Москва, 1987, с. 488.

57 Opisanie nieszczęsliwej klęski przez wojsko Litewskie poniesionej pod Stolowiczami Ru 1771 w Nowogrodzkiem MAB RS f. 18-206/1, p. 187-189.

58 Suvorovas teigia, kad puole tik 500 karių, 200 buvo rezerve. 17710914 A. Suvorovo laiškas gen. M. N. Krečetnikovui//Суворов А. Письма. Москва, 1987, с. 21

59 Opisanie nieszczęsliwej klęski przez wojsko Litewskie poniesionej pod Stolowiczami Ru 1771 w Nowogrodzkiem. MAB RS f. 18, b.206/1, p. 187-189.

${ }^{60}$ List JW ImciPana Ogińskiego Hetmana WXLitt pisany z Królewstwa do Jednego z swoich Przyjacioł Datt 29 Września a pisany 3 dnia po zbiciu swoim. MAB, f. 255-1301, s. 798.
} 
mūšio etapą, kuris irgi baigèsi nesėkmingai. Mūšyje žuvo rotmistras Puzyna, stovyklininkas (stanowniczy) Šveikovskis (Szwejkowski), raštininkas Kolontajus (Kołłątaj), pulkininkai Kirabneris, audringas, pulkininkai leitenantai Volanas (Wolan), Paplonskis (Papłoński), majoras Kochanovskis (Kochanowski), janyčarų rotmistras Narmontavičius (Narmontowicz), artilerijos kapitonas Freitagas, leitenantai Surynas, Hoppenfeldas, Laskovskis, janičarų leitenantas Turčevskis, kunigas Znatovičius (Znatowicz), neịvardinti, bet greičiausiai vẻliavininkai Soroka, Mykolas Stravinskis, Giedraitis, Šancimskis (Szancimski), Stoskovskis, Rostockis, petihorų vėliavininkas Zavadzkis, etmono virtuvininkas Šakevičius (Szakiewicz), bereiteris, regimento felčeris Plevo, felčeris Cilichas, kitų karių 364, tarp jų oberceigvarto J. Zaborovskio brolis, o sūnus buvo 18 kartų sužeistas ${ }^{61}$. Pagal rusų duomenis, buvo paimtos visos 12 patrankų, visa gurguolè, ị nelaisvę paimta 300 karių, žuvo apie 500 karių. Savus nuostolius Aleksandras Suvorovas vertino 8 žuvusiais ir 80 sužeistų ${ }^{62}$.

Kokias išvadas galima padaryti iš šio mūšio analizès. Pirmiausiai pasirodè, kad M. K. Oginskis nesugebejjo teisingai įvertinti situacijos, suvokti Bielako ir kitų karių duoto patarimo, netinkamai pasirinko patarejjus ir neužtikrino pakankamos tvarkos stovykloje. Antra, pasirodè, kad Lietuvos pėstininkai nebuvo psichologiškai parengti mūšiui, nors atskiri karininkai su savo žmonèmis ir bandè kontraatakuoti. Trečia, didelès įtakos turëjo išdavystė kariuomenèje, kurią mini beveik visi, bet nèra patikimų žinių, kas buvo tie išdavikai. Turima medžiaga leistų manyti, kad būtent Chominskis, i̇vardintas kaip LDK kariuomenei vadovavęs žmogus etmono vardu, ir buvo pagrindinis, kuris trukdè priimti tinkamą sprendimą, - taip yra aprašyta liudininko pasakojime ${ }^{63}$, tai įrodytų ir ankstesnè bei vélesnè jo veikla, visada palanki Rusijai ${ }^{64}$.

Atskiros analizės reikalautų lietuvių sargybų pastatymo sistema. Kaip galima spręsti iš DB priešakinès sargybos pulko nuostolių aprašymo, būtent šio pulko kariai èjo sargybą miestelio aikštėje bei poste prie Miro kelio. Taip

61 Vyriausiojo ceigvarto Jano Zaborovskio pasakojimas. LVIA, f. SA, b. 18369, 1. 406-408. Ten pat. Dalis pavardžių sutampa ir su: Opisanie nieszczęsliwej klęski przez wojsko Litewskie poniesionej pod Stolowiczami Ru 1771 w Nowogrodzkiem MAB RS f. 18-206/1, p. 187-189.

6217710914 A. Suvorovo laiškas gen. M. N. Krečetnikovui. //Суворов А. Письма. Москва, 1987, c. 21, ir komentaras c. 488.

63 Zaleski M. Pamiętniki Michała Zaleskiego, wojskiego Wielkiego Księstwa Litewskiego, posla na sejm czteroletni. Poznanń, 1879, s. 41-42.

${ }^{64}$ Konopczyński W. PSB, T. 3. Chominski Franciszek Ksawery, s. 416-417. 
pat minima, kad, prasidèjus mūšiui, dalis pulko karių bandẻ ateiti aikštės sargybai ị pagalbą ir šios kontratakos metu patyrẻ nuostolių ${ }^{65}$.

Rusijos kariuomenè nepasitenkino pergale ir èmé persekioti garsiuosius totorių pulkus, kurie, būdami pasirengę, palyginus mažai nukentèjo Stolovičių kautynėse. Rugsėjo 30 d. prie Golnos kaimo totorius užklupo gen. Diuringo rusų dalinys, kuriam totoriai nusprendè pasiduoti, o valdovui pasiunte laišką, prašydami atleidimo. Valdovo rūpesčiu Rusijos ambasadorius Saldernas atleido abiem pulkams dẻl jų nepastovumo kilusius žygius ir išsiuntė atitinkamą raštą, tačiau jau dieną prieš tai gen. Drevicas, tarsi nežinodamas apie Bielako ir Koryckio pasidavimą spalio 2 d., netikètai užpuolė pulkus ir išžude kelis šimtus ulonų ${ }^{66}$.

\section{Kovų pabaiga}

Iš Lietuvos kariuomenès tik garsieji totorių daliniai kovojo $1772 \mathrm{~m}$. pavasario kampanijoje. $1772 \mathrm{~m}$. vasario mèn. Koryckio pulkas buvo perduotas Branickio pavaldumui ir dalyvavo kovose prie Krokuvos, Vavelio šturme, vẻliau dalyvavo apsiausties priedangoje nuo pagalbos skubančiu konfederatų. Vasario mèn. 25 d. mūšyje prie Volos patyrẻ pralaimejjimą prieš Krokuvos pulkininko Grabskio pajègas. Kovo ir balandžio mèn. dalyvavo paskutinèse Lietuvos konfederatų kovose Priekarpatėje: sumuše jų pajėgas prie Žyvco, îveikè Ipolitą Kadlubiski prie Kryžovo ir gen. Antaną Šiucą prie Ščerko. Po konfederacijos pralaimèjimo totoriai buvo grąžinti ị savo dislokacijos vietą Sucha Vola ${ }^{67}$.

Po didžiosios nelaimès kariuomenès vadovybė buvo palikta lauko etmonui Sapiegai, Karo komisija uždraudė dalytis ị atskiras partijas, neklausyti kitų vadų, kad galima būtų išlikti ${ }^{68}$. Jau 1772 m. birželio kadencijos metu buvo liepta pateikti žinias apie buvusius nuostolius: užmuštus, paimtus ị nelaisvę, patyrusius nuostolius, nebuvo tikimasi visų reikalus išspręsti, bet

\footnotetext{
65 Regestr straty Sałey Acyi w misteczku Stołłowiczach w roku przeszłym 1771 in 7-bri a w roku 1772 do JW IM pana Alexandrowicza koniuszego WWXtwa Littego Regimantarza dywizji Litewskiey poddje się. LVIA, f. SA, b. 18255, l. 210-211.

${ }^{66}$ Kryczyński S. Bielak Józef. PSB, T. II, Kraków, 1936, s. 33; Szczygielski W. Korycki Aleksander Mustafa. PSB, T. XIV, 1968-1969, s. 137.

67 Szczygielski W. Korycki Aleksander Mustafa. PSB, T. XIV, 1968-1969, s. 137.

6817720117 Sancitum in Ordine ubiezpieczenia Woyska Rzeczypospolitej. LVIA, f. SA, b. $18252,1.21$
} 
galvota palengva imti taisyti padètic ${ }^{69} .1773 \mathrm{~m}$. Seimui buvo pasiųstas informuojamasis raštas apie sunkią padètị, kad $1766 \mathrm{~m}$. Seimo sprendimas nebuvo ịgyvendintas, kad Baltarusijos divizijos vėliavos rusų kordoną užtraukus negauna algų, prašè padėti pabaigti invalidų namų statybą ${ }^{70}$. Karininkams algos mokamos buvo nereguliariai, valstybė buvo skolinga kai kuriems dalinių šefams, pavyzdžiui, LDK gvardijos pèstininkų regimento šefui Adomui Čartoriskiui LDK iždas buvo skolingas 135801 auksinus, skola kitam šefui siekė 36000 auksinų $^{71}$. Po $1771 \mathrm{~m}$. ìvykių Lietuvos kariuomenès gyvenimas vẻl grịžo ị savo seną vagą, tačiau ne visi daliniai buvo iki galo sukomplektuoti. $1772 \mathrm{~m}$. vasarą buvo išleisti įsakymai, kurių metu buvo bandoma bent jau identifikuoti, kokia padètis tautinès kavalerijos vèliavose ${ }^{72}$. DB janičaru vèliava buvo pradèta atkurti jau 1772 m.: 1772 m. vasarą (birželio 13 d.) joje buvo tik 55 kariai, iš jų 37 eiliniai, o jau metų pabaigoje papildomai buvo užverbuoti 28 žmonès, iš jų 6 muzikantai ir 22 eiliniai $^{73}$. $1772 \mathrm{~m}$. pr. Bielako pulke buvo 397 kariai iš numatytų 400, bet trūko 98 žirgų, metų viduryje šis trūkumas sumažẻjo iki 32 žirgų, o be jų kariai negalejo tarnauti ${ }^{74}$. JKM Baranovskio priešakinès sargybos pulkui 1772 m. vid. trūko 194 karių. Po I valstybės padalijimo kai kurie daliniai nebeturẻjo galimybių gauti nustatytų algų, todèl teko vykdyti redukciją, mažinant puskarininkių ir eilinių kareivių etatus $^{75}$. Pavyzdžiui, jau 1774 m. lapkričio mėn. DB pėstininkų pulke buvo tik 205 kariai vietoj reikiamų 291, trūko 2 kapitonų, 1 leitenanto, auditoriaus, kelių puskarininkių ir 86 eilinių, tačiau jame buvo du pulkininkai ir du pulkininkai leitenantai ${ }^{76}$, o $1775 \mathrm{~m}$. rugsejjo $1 \mathrm{~d}$. LB péstininkų pulko komplektacija jau atitiko nustatytus etatus.

Atskira problema tapo LDK kariuomenès daliniai, I padalijimo metu atsidūrę „už kordono“, t. y. Rusijos okupuotose teritorijose. Iš Baltarusijos divizijos tokiu būdu liko dalis Polocko, Homelio, Dysnos ir Čečersko vẻliavų ${ }^{77}$.

\footnotetext{
6917720619 Sancitum in Ordine Summy larginacyniney. LVIA, f. SA, b. 18252, 1. 22.

7017730703 Sancitum ị seimą. LVIA, f. SA, b. 18252, 1. 29-30.

71 Górski K. Historia piechoty polskiej. Kraków, 1893, s. 115.

7217720623 ịsakymai Tautinès kavalerijos diviziju regimentoriams. LVIA, f. SA, b. 18256, 1. 4-6.

7317720613 ir 17721226 DB janyčarų vẻliavos raportai LDK karo komisijai. LVIA, f. SA, b. $18255,1.172$ ir 176.

74177201 ir 177206 Bielako pulko raportai karo komisijai . LVIA, f. SA, b. 18255, 1. 186-187

75 Górski K. Historia piechoty polskiej. Kraków, 1893, s. 115.

7617741101 DB péstininkų pulko raportas iš Derečino. VU RS, F. 4, b. 11484.

77 Baltarusijos divizijos vẻliavoms išmokètų sumų už 1771 metų rugsèjo ratą. LVIA, f. SA, b. 18255, 1. 208.
} 


\section{Išvados}

1. Lietuvos kariuomenė Baro konfederacijos metu 1768-1770 m. užėmė neutralią poziciją kovojančių šalių atžvilgiu, nors atskiri daliniai prievarta ar ịkalbinejjimais būdavo ịtraukiami ị kovų sūkurị. Tokią poziciją lèmė didžiojo etmono Mykolo Kazimiero Oginskio politika, nukreipta i pajẻgų išsaugojimą ir savųjų etmono prerogatyvų gynimą.

2. Vertingiausią Lietuvos kariuomenès dali sudarè Bielako ir Koryckio totorių pulkai, aktyviai dalyvavę kovose abiejose kovojančiose pusėse. Jų vadai, būdami puikūs kovotojai, sunkiai orientavosi sudètingose ir prieštaringose politinėse Baro konfederacijos peripetijose, dažnai keite kovos frontą, todèl jokio apčiuopiamo rezultato pasiekti nepavyko, nors ir buvo apginta jų, kaip kovotojų, reputacija.

3. Svetimšalių autoramento daliniai 1768-1772 m. laikotarpiu buvo mažesnio dydžio, nei buvo numatyta etate ir reguliaminuose, ypač mažai turëjo žirgų. Labai didelè dalis karininkų buvo išleisti atostogų, o tai negalejjo neturèti ịtakos dalinių kovinio parengimo lygiui. Aprūpinimo ir parengimo lygiu išsiskyre tiesiogiai etmonui pavaldus Didžiosios buožès raitelių regimentas.

4. Tautinio autoramento husarų ir petihorų vẻliavos buvo ypač prastos būklès, jų karininkai ir draugai egzistavo, išskyrus vietininkus, tik popieriuje, todèl tokios vẻliavos tapdavo lengvu konfederatų grobiu, tačiau ir konfederatų sudètyje iš jų buvo mažai naudos. Priešakinés sargybos pulkai buvo organizuoti stipriau, tačiau jiems trūko aprūpinimo sistemos ir tikro kovinio parengimo.

5. $1771 \mathrm{~m}$. rugsejo mèn. Lietuvos kariuomenè, kaip organizuota jèga, sugebėjo vieningai stoti ị kovą, drąsiai išsiveržè iš apsupimo, privertẻ Rusijos kariuomenę pasitelkti dideles jẻgas, laimèjo reguliarų mūšš puolant Bezdzežo miesteli, tačiau visas jos ir jos vado Mykolo Kazimiero Oginskio pergales nubraukẻ sẻkmingas įžūlus Aleksandro Suvorovo pajẻgų puolimas Stolovičiuose. Pralaimejjimas buvo atsitiktinis, tačiau vado bẻgimas turèjo svarbią moralinę reikšmę, pakirtusią karių pasitikèjimą vadu ir savo jẻgomis, ir virto katastrofa.

6. $1771 \mathrm{~m}$. rudens $-1772 \mathrm{~m}$. pavasario laikotarpiu Lietuvos kariuomenẻ buvo pasiekusi savo žemiausią smukimo tašką: daliniuose trūko karių, daliniai buvo praradę savo pinigus, ginklus ir kitą turtą, tačiau jau $1772 \mathrm{~m}$. pavasarị padètis èmé gerèti, kol $1775 \mathrm{~m}$. pasiekè ikikarinị lygị.

7. Mykolo Kazimiero Oginskio vykdyta laipsnių dalinimo politika, blogi santykiai su Iždo komisija ir patirtas pralaimejjimas lẻmé apskritai prastą kariuomenės būklę 1775-1776 m. reformų išvakarėse. 


\title{
Résumé
}

\section{L'armée du Grand Duché de Lituanie pendant la Confédération de Bar en 1768-1772}

\author{
Dr. Valdas Rakutis, \\ Académie militaire de Lituanie de Général Jonas Žemaitis
}

En 1768-1772, sur le territoire de la République de Deux Peuples, les luttes entre la Confédération de Bar et les armées de l'empire de Russie avec le souverain Stanislovas Augustas Poniatovskis ont eu lieu. Le but de l'article - parcourir l'activité de l'armée de la Lituanie pendant la Confédération de Bar en 1768-1772. Les objets de l'article :

1. Évaluer le comportement politique des dirigeant supérieurs et des commandants des unités

2. Faire l'analyse quantitative et qualitative de l'armée

3. Parcourir l'activité militaire de l'armée de la Lituanie et de ses unités, en analysant les batailles et les confrontations

4. Évaluer l'influence des batailles de la Confédération de Bar sur l'armée.

L'armée de la Lituanie a eu la position politique neutre pendant la Confédération de Bar en 1768-1770, mais quelques unités de l'armée ont participé dans les batailles. Cette position reflète stratégie du commandant Mykolas Kazimieras Oginskis, qui a eu l'intention de protéger l'armée lituanienne et de défendre ses propres priorités.

Les unités de l'armée lituanienne les plus appréciés étaient les régiments des Tatars de Bielakas et de Koryckis qui participaient dans les batailles pour toutes les deux parties en guerre. Dans les années 1968 - 1772, les régiments des étrangers ont été plus petits que prévoyait les règlements, surtout, ils n'avaient pas assez de chevaux. La plus grande partie des officiers ont été en vacances, et cela a vraiment influencé le niveau de préparation des régiments. Les drapeaux des hussards et des cavaliers ont été si pauvres que la Confédération de Bar gagnaient facilement, mais ces régiments n'étaient pas utiles. Les troupes de la garde du devant étaient mieux organisées, mais elles manquaient de système de fournissement et de préparation militaire.

Au mois de septembre 1771, l'armée de la Lituanie a réussi à commencer la bataille comme une force organisée, l'armée de la Russie a du mobi- 
liser ses forces, les lituaniens ont gagné la bataille de la ville de Bezdzežas, mais les unités d'Aleksandr Suvorov ont attaqué à Stolovitch et elles ont gagnés. Une défaite a été accidentelle, mais la fuite du commandant a eu une grande importance, les soldats n'avaient plus de confiance en leur commandant et en leurs forces.

Pendant la période de l'automne de 1771 jusqu'au printemps de 1772, la situation de l'armée de la Lituanie a été vraiment le pire: les divisions manquaient de soldats, de ressources, d'armes et d'autres biens, mais au printemps de 1772, la situation a commencé à s'améliorer et en 1775, elle a atteint le niveau de l'avant guerre.

La politique des grades, les relations insuffisantes avec la commission du Trésor et une défaite de Mykolas Kazimieras Oginskis - tous ces facteurs ont influencé vraiment pauvre état de l'armée à la veille des reformes des années 1775-1776. 


\section{PRIEDAI}

Priedas nr. 1. Lietuvos kariuomenès ir jos dalinių vadai 1768-1772 m. ${ }^{78}$

\section{Vadovybė}

\begin{tabular}{|c|c|c|}
\hline Dalinys & Vadai & $\begin{array}{l}\text { Dalinio vado ir padalinių pozicija } \\
\text { kovų metu. }\end{array}$ \\
\hline $\begin{array}{l}\text { Vyriausioji vadovybė: } \\
\text { etmonai }\end{array}$ & $\begin{array}{l}\text { Didysis etmo- } \\
\text { nas Mykolas K. } \\
\text { Oginskis (nuo } \\
17680229\end{array}$ & $\begin{array}{l}\text { Iki } 1771 \text { m. atvirai nesidèjo prie } \\
\text { jokios kovojančios pusès, nors pa- } \\
\text { laikė santykius su Baro konfedera- } \\
\text { cijos pareigūnais ir žadejo prisidėti. } \\
1771 \text { m. vasaros pab. atvirai peréjo } \\
\text { i konfederatu pusę, su visa kariuo- } \\
\text { mene dalyvavo Bezdzežo ir Stolo- } \\
\text { vičiu mūšiuose, po pralaimejimo } \\
\text { pasitrauke emigracijon ir ten toliau } \\
\text { buvo tituluojamas etmonu ir etati- } \\
\text { nès Lietuvos kariuomenès vadu. }\end{array}$ \\
\hline $\begin{array}{l}\text { Vyriausioji vadovybė: } \\
\text { etmonai }\end{array}$ & $\begin{array}{l}\text { Lauko etmonas } \\
\text { Juozapas Sapiega }\end{array}$ & Laikèsi neutraliai. \\
\hline Generalinis štabas & $\begin{array}{l}\text { Lauko raštinin- } \\
\text { kas Jozefas Sos- } \\
\text { novskis }\end{array}$ & $\begin{array}{l}\text { Karo komisijos komisaras, rusų } \\
\text { žmogus, informavęs Rusijos vado- } \\
\text { vybę apie Karo komisijos veiklą. }\end{array}$ \\
\hline Generalinis štabas & $\begin{array}{l}\text { Lauko sargybi- } \\
\text { ninkas Ksaveras } \\
\text { Oginskis (1768 } \\
1223 \text { ) } \\
\end{array}$ & \\
\hline Generalinis štabas & $\begin{array}{l}\text { Lauko stovy- } \\
\text { klininkas Ignas } \\
\text { Giedraitis (1769 } \\
0109) \\
\end{array}$ & \\
\hline Generalinis štabas & $\begin{array}{l}\text { LDK arklininkas } \\
\text { (stanowniczy) } \\
\text { Sveikovskis }\end{array}$ & Žuvo Stolovičių mūšyje. \\
\hline Generalinis štabas & $\begin{array}{l}\text { LDK kasininkas } \\
\text { Kolontajus }\end{array}$ & Žuvo Stolovičių mūšyje. \\
\hline $\begin{array}{l}\text { Aktualūs Lietuvos } \\
\text { kariuomenès genero- } \\
\text { lai be dalinio }\end{array}$ & $\begin{array}{l}\text { Gen. mjr. Jonas } \\
\text { Jurgis Grabovskis }\end{array}$ & \\
\hline
\end{tabular}

${ }^{78}$ Duomenys paimti iš visų straipsnyje minètų LVIA saugomų dokumentų. 


\begin{tabular}{|l|l|l|}
\hline & $\begin{array}{l}\text { Gen. ltn. Radvila. } \\
\text { Péstininkų gene- } \\
\text { rolas leitenantas }\end{array}$ & \\
\hline & $\begin{array}{l}\text { Etmono patikè- } \\
\text { tinis Pranciškus } \\
\text { Ksaveras Cho- } \\
\text { minskis }\end{array}$ & $\begin{array}{l}\text { Buvo etmono diplomatijos ir } \\
\text { karinių reikalu patikètinis, po } \\
\text { Stolovičį buvo Sapiegų apšauktas } \\
\text { išdaviku, ką patvirtina ir kiti doku- } \\
\text { mentai*. }\end{array}$ \\
\hline
\end{tabular}

* Konopczyński W. Chominski Franciszek Ksawery. PSB, t. 3, s. 416-417.

\section{Tautinis autoramentas}

\begin{tabular}{|l|l|l|}
\hline Tautine kavalerija: & & \\
\hline Žemaičių divizija & $\begin{array}{l}\text { Regimentoriai } \\
\text { Mykolas Korvinas } \\
\text { Kosakovskis, } \\
\text { Cheltchovskis } \\
\text { Puzyna (1770 12 } \\
\text { 20), } \\
\text { Górskis, Žemaiti- } \\
\text { jos kaštelionas }\end{array}$ & \\
\hline Lietuvos divizija & $\begin{array}{l}\text { Regimentorius } \\
\text { Aleksandravičius, } \\
\text { LDK arklidininkas }\end{array}$ & \\
\hline Baltarusijos divizija & $\begin{array}{l}\text { Regimentorius } \\
\text { Mikalojus Chrapo- } \\
\text { vickis }\end{array}$ & \\
\hline $\begin{array}{l}\text { Priešakinės sargybos } \\
\text { pulkai: }\end{array}$ & $\begin{array}{l}\text { Plk. Jonušas Bara- } \\
\text { novskis (nuo 1768 } \\
\text { 06 20) }\end{array}$ & \\
\hline $\begin{array}{l}\text { JKM Baranovskio } \\
\text { pulkas }\end{array}$ & $\begin{array}{l}\text { Plk. Tomas Ma- } \\
\text { salskis }\end{array}$ & \\
\hline $\begin{array}{l}\text { DB priešakinės sar- } \\
\text { gybos pulkas }\end{array}$ & $\begin{array}{l}\text { Plk. Paškovskis } \\
\text { 1. e. Bilat Achma- } \\
\text { tovičius (1769 01 } \\
\text { 12) }\end{array}$ & \\
\hline $\begin{array}{l}\text { LB priešakinės sar- } \\
\text { gybos pulkas }\end{array}$ & $\begin{array}{l}\text { Plk. Aleksandras } \\
\text { Mustafa Koryckis }\end{array}$ & \\
\hline $\begin{array}{l}\text { Koryckio totoriu } \\
\text { pulkas }\end{array}$ & $\begin{array}{l}\text { Plk. (gen. mjr.) } \\
\text { Juozas Bielakas }\end{array}$ & \\
\hline $\begin{array}{l}\text { Bielako totoriu pul } \\
\text { kas }\end{array}$ & \\
\hline
\end{tabular}




\section{Svetimšaliu autoramentas}

\begin{tabular}{|c|c|c|}
\hline \multicolumn{3}{|l|}{ Kavalerija: } \\
\hline $\begin{array}{l}\text { JKM raitelių leibre- } \\
\text { gimentas }\end{array}$ & $\begin{array}{l}\text { Gen. mjr. Mykolas } \\
\text { Grigalius Gra- } \\
\text { bovskis }\end{array}$ & $\begin{array}{l}\text { Kartu su savo daliniu aktyviai ko- } \\
\text { vojo su Baro konfederatais } \\
\text { P. K. Branickio pajëgų sudettyje. }\end{array}$ \\
\hline $\begin{array}{l}\text { DB raitelių regi- } \\
\text { mentas }\end{array}$ & $\begin{array}{l}\text { Antanas Tiškevi- } \\
\text { čius (1768 12 22) }\end{array}$ & \\
\hline $\begin{array}{l}\text { LB raitelių regimen- } \\
\text { tas }\end{array}$ & Juozapas Radvila & \\
\hline $\begin{array}{l}\text { Pinsko Grabovskio } \\
\text { raitelių regimentas }\end{array}$ & $\begin{array}{l}1771 \text { m. Povilas } \\
\text { Jurgis Grabovskis* }\end{array}$ & \\
\hline \multicolumn{3}{|l|}{ Pèstininkai } \\
\hline $\begin{array}{l}\text { JKM pėstininkų } \\
\text { gvardijos regimentas }\end{array}$ & $\begin{array}{l}\text { Gen. mjr. Jonas } \\
\text { Jurgis Grabovskis }\end{array}$ & $\begin{array}{l}\text { Vadas buvo žinomas disidentas } \\
\text { Slucko konfedracijos, Rusijos } \\
\text { šalininkas ir Stanislovo Augusto } \\
\text { meilužès vyras, nukentejo nuo } \\
\text { Baro konfederatų. Dalinys kartu } \\
\text { su kitais daliniais turėjo dalyvauti } \\
\text { Baro kovose P. K. Branickio pajè- } \\
\text { gų sudetyje. }\end{array}$ \\
\hline $\begin{array}{l}\text { DB pėstininkų regi- } \\
\text { mentas }\end{array}$ & Oskierko & \\
\hline $\begin{array}{l}\text { LB pèstininkų regi- } \\
\text { mentas }\end{array}$ & $\begin{array}{l}\text { Gen.mjr. Steponas } \\
\text { Sližnius }\end{array}$ & \\
\hline DB janičarų vèliava & $\begin{array}{l}\text { Rtm. Juozas Nar- } \\
\text { muntovičius }\end{array}$ & $\begin{array}{l}\text { Stipriai nukentėjo Stlovičių mūšyje } \\
(17710922) \text {. }\end{array}$ \\
\hline LB janičarų vèliava & Rtm. Korsakas & \\
\hline \multicolumn{3}{|l|}{ LDK maršalo vèliava } \\
\hline LDK iždo vèliava & $\begin{array}{l}\text { Rtm. Mykolas } \\
\text { Devičas }\end{array}$ & \\
\hline $\begin{array}{l}\text { LDK vyriausiojo } \\
\text { tribunolo vèliava }\end{array}$ & $\begin{array}{l}\text { Rtm. Bogdaševs- } \\
\text { kis }\end{array}$ & \\
\hline Artilerijos korpusas & & $\begin{array}{l}\text { Dalyvavo Bezdzežo mūšyje, patyrè } \\
\text { nuostolių Stolovičiu mūšyje. }\end{array}$ \\
\hline
\end{tabular}

* 5 pèstininku pulko vadai NMB, RS F76-50. 
Priedas nr. 2 LDK kariuomenè 1771 m. rudenị (veiksmai) ${ }^{79}$.

\begin{tabular}{|c|c|c|c|}
\hline Dalinys & Buvo & $\begin{array}{l}\text { Iš jų daly- } \\
\text { vavo mū- } \\
\text { šyje }\end{array}$ & Nuostoliai \\
\hline Tautinè kavalerija: & Dalyvavo & $\begin{array}{l}\text { Tikrai daly- } \\
\text { vavo }\end{array}$ & $\begin{array}{l}\text { Patirti dideli } \\
\text { nuostoliai: nete- } \\
\text { ko žirgu, ginklų } \\
\text { ir daiktŭ, keletas } \\
\text { paimta î nelaisvę, } \\
\text { keletas žuvusių } \\
\text { eilinių. }\end{array}$ \\
\hline Žemaičių divizija & Dalyvavo & & $\begin{array}{l}142 \text { paimti ị ne- } \\
\text { laisvę. }\end{array}$ \\
\hline Lietuvos divizija & $\begin{array}{l}\text { Tikrai dalyvavo } \\
\text { divizijai priskirtas } \\
\text { DB priešakinès } \\
\text { sargybos pulkas. }\end{array}$ & & \\
\hline Baltarusijos divizija & Dalyvavo & & \\
\hline \multicolumn{4}{|l|}{$\begin{array}{l}\text { Priešakinès sargybos } \\
\text { pulkai: }\end{array}$} \\
\hline $\begin{array}{l}\text { JKM Baranovskio pul- } \\
\text { kas }\end{array}$ & Dalyvavo & & \\
\hline $\begin{array}{l}\text { DB priešakinès sargybos } \\
\text { pulkas }\end{array}$ & Dalyvavo & $\begin{array}{l}\text { Dalyvavo ir } \\
\text { nuostoliu } \\
\text { patyre } 5 \\
\text { vėliavos. }\end{array}$ & $\begin{array}{l}11 \text { eilinių ir } 44 \\
\text { žirgai, nuostoliai } \\
\text { ivertinti } 8964 \\
\text { auksinais*. }\end{array}$ \\
\hline \multicolumn{4}{|l|}{$\begin{array}{l}\text { LB priešakinès sargybos } \\
\text { pulkas }\end{array}$} \\
\hline Koryckio totoriu pulkas & Dalyvavo & & $\begin{array}{l}\text { Patyrè nežymių } \\
\text { nuostoliu mūšy- } \\
\text { je, bet išžudyti } \\
\text { kariai. }\end{array}$ \\
\hline Bielako totorių pulkas & Dalyvavo & & $\begin{array}{l}\text { Patyrė nežymių } \\
\text { nuostoliu, bet } \\
\text { išžudyti kariai. }\end{array}$ \\
\hline $\begin{array}{l}\text { Svetimšalių autoramen- } \\
\text { tas } \\
\text { Kavalerija: }\end{array}$ & & & \\
\hline
\end{tabular}

${ }^{79}$ Sudaryta remiantis LVIA, F. SA. B. 18255, 1. 164-224 pateiktais 1772 metu Lietuvos kariuomenès dalinių raportais. 


\begin{tabular}{|c|c|c|c|}
\hline $\begin{array}{l}\text { JKM raitelių leibregi- } \\
\text { mentas }\end{array}$ & Nedalyvavo & & \\
\hline DB raitelių regimentas & $\begin{array}{l}153 \text { kariai/70 } \\
\text { žirgų. }\end{array}$ & & \\
\hline LB raitelių regimentas & 198 & & \\
\hline $\begin{array}{l}\text { Pinsko Grabovskio raite- } \\
\text { lių regimentas }\end{array}$ & $\begin{array}{l}\text { 83-99 kariai/20 } \\
\text { žirgų }\end{array}$ & & \\
\hline \multicolumn{4}{|l|}{ Pèstininkai } \\
\hline $\begin{array}{l}\text { JKM pėstininku gvardi- } \\
\text { jos regimentas }\end{array}$ & Nedalyvavo & & \\
\hline $\begin{array}{l}\text { DB pèstininkų regimen- } \\
\text { tas }\end{array}$ & 276 kariai & & \\
\hline $\begin{array}{l}\text { LB pėstininkų regimen- } \\
\text { tas }\end{array}$ & 244 & 117 & $\begin{array}{l}\text { I nelaisvę pateko: } \\
1 \text { karininkas, } 8 \\
\text { puskarininkiai ir } \\
\text { muzikantai bei } 36 \\
\text { kareiviai. } \\
\text { Sužeistas } 1 \text { ka- } \\
\text { reivis. } \\
\text { Be žinios dingo } \\
30 \text {, nenukentejo } \\
\text { tik } 17 \text { kareivių. }\end{array}$ \\
\hline DB janičarų vèliava & 109 & & $\begin{array}{l}\text { Patyrè labai dide- } \\
\text { lių nuostolių. }\end{array}$ \\
\hline LB janičarų vėliava & Nežinoma & & \\
\hline LDK maršalo vèliava & Nežinoma & & \\
\hline $\begin{array}{l}\text { LDK Vyriausiojo tribu- } \\
\text { nolo vėliava }\end{array}$ & 69 & & \\
\hline Artilerijos korpusas & Dalyvavo & & $\begin{array}{l}\text { Patyre didelių } \\
\text { nuostolių, neteko } \\
\text { pabūklu, amuni- } \\
\text { cijos ir asmeninių } \\
\text { vežimų. }\end{array}$ \\
\hline
\end{tabular}

* Regestr straty... LVIA, f. SA, 18255, b. , 1. 210-211. 
Priedas nr. 3 LDK kariuomenė Baro kovoms pasibaigus 1772 m. vid.

\begin{tabular}{|c|c|c|c|c|}
\hline Dalinys & $\begin{array}{l}\text { Turi } \\
\text { būti }\end{array}$ & Yra & Trūksta & Perteklius \\
\hline \multicolumn{5}{|l|}{ TAUTINĖ KAVALERIJA: } \\
\hline \multicolumn{5}{|l|}{ Žemaičiu divizija } \\
\hline \multicolumn{5}{|l|}{ Lietuvos divizija } \\
\hline \multicolumn{5}{|l|}{ Baltarusijos divizija } \\
\hline \multicolumn{5}{|l|}{ Priešakinès sargybos pulkai: } \\
\hline JKM Baranovskio pulkas & & 189 & 194 & \\
\hline \multicolumn{5}{|l|}{ DB priešakinès sargybos pulkas } \\
\hline \multicolumn{5}{|l|}{ LB priešakinės sargybos pulkas } \\
\hline \multicolumn{5}{|l|}{ Koryckio totorių pulkas } \\
\hline Bielako totoriu pulkas & 400 & 393 & $\begin{array}{l}7 \text { karių ir } \\
32 \text { žirgų }\end{array}$ & \\
\hline \multicolumn{5}{|l|}{$\begin{array}{l}\text { SVETIMŠALIŲ AUTORA- } \\
\text { MENTAS } \\
\text { Kavalerija: }\end{array}$} \\
\hline \multicolumn{5}{|l|}{ JKM raitelių leibregimentas } \\
\hline DB raitelių regimentas & & 138 & $\begin{array}{c}1 \text { kari- } \\
\text { ninko, } \\
19 \text { eilinių } \\
\text { bei } 69 \\
\text { žirgų }\end{array}$ & $\begin{array}{l}4 \text { karinin- } \\
\text { kai. }\end{array}$ \\
\hline LB raitelių regimentas & $\begin{array}{l}198 \mathrm{ka}- \\
\text { riai, } 181 \\
\text { žirgas. }\end{array}$ & $\begin{array}{l}146 \mathrm{ka-} \\
\text { riai, } 60 \\
\text { žirgų. }\end{array}$ & $\begin{array}{l}58 \text { kariu, } \\
121 \text { žir- } \\
\text { go. }\end{array}$ & $\begin{array}{l}6 \text { karinin- } \\
\text { kai. }\end{array}$ \\
\hline $\begin{array}{l}\text { Pinsko Grabovskio raitelių re- } \\
\text { gimentas }\end{array}$ & & $\begin{array}{l}94 \mathrm{ka}- \\
\text { riai, } 20 \\
\text { žirgų. }\end{array}$ & & \\
\hline \multicolumn{5}{|l|}{$\begin{array}{l}\text { SVETIMŠALIŲ AUTORA- } \\
\text { MENTAS } \\
\text { Pėstininkai }\end{array}$} \\
\hline \multicolumn{5}{|l|}{$\begin{array}{l}\text { JKM pėstininkų gvardijos regi- } \\
\text { mentas }\end{array}$} \\
\hline DB pėstininkų regimentas & $\begin{array}{l}276 \mathrm{ka}- \\
\text { riai. }\end{array}$ & 156 & $\begin{array}{l}\text { 126, dau- } \\
\text { giausiai } \\
(118) \\
\text { kareivių. }\end{array}$ & $\begin{array}{c}\text { 11, dau- } \\
\text { giausiai } \\
\text { karininkų. }\end{array}$ \\
\hline
\end{tabular}




\begin{tabular}{|c|c|c|c|}
\hline LB pèstininkų regimentas & & 182 & $\begin{array}{c}6 \text { kadetų } \\
\text { ir } 55 \mathrm{ka}- \\
\text { reivių. }\end{array}$ \\
\hline DB janičarų vèliava & 109 & 80 & 29 \\
\hline LB janičarų vėliava & & 63 & \\
\hline \multicolumn{4}{|l|}{ LDK maršalo vėliava } \\
\hline $\begin{array}{l}\text { LDK vyriausiojo tribunolo vè- } \\
\text { liava }\end{array}$ & 69 & 59 & \\
\hline Artilerijos korpusas & & 117 & 10 \\
\hline
\end{tabular}

Iteikta 2005-11-17 